\title{
Kaspars Auslands
}

\section{DIVU UN VAIRĀKU CEREBRĀLU METASTĀŽU KOMPLEKSAS ĀRSTĚŠANAS IESPĒJAS}

Promocijas darba kopsavilkums medicinas doktora zinātniskā grāda iegūšanai

$$
\text { Specialitāte - neiroḳirurğija }
$$

$$
\text { Rīga, } 2015
$$




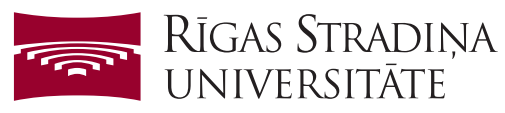

Kaspars Auslands

\title{
DIVU UN VAIRĀKU CEREBRĀLU METASTĀŽU KOMPLEKSAS ĀRSTĒŠANAS IESPĒJAS
}

\author{
Promocijas darba kopsavilkums \\ medicīnas doktora zinātniskā grāda iegūšanai
}

Specialitāte - neiroķirurg̊ija

Rīga, 2015 
Promocijas darbs izstrādāts Rīgas Stradiṇa universitātes Neiroloǵijas un neiroķirurğijas katedras klīniskajā bāzē - Rīgas Austrumu klīniskās universitātes slimnīcas (RAKUS) klīnikā "Gaiļezers" (nodaļas vadītāji dr. K. Bicāns, prof. J. Ozolinšš ) - sadarbībā ar Latvijas Onkologijas centra Terapeitiskās radiologíjas un medicīnas fizikas klīniku (vadītāja Dr. med. docente O. Utehina) un Staru terapijas nodaļu (vadītāja - Z. Liepa). Radiologiskā diagnostika un terapijas kontrole galvenokārt veikta Radioloǵijas katedras klīniskajā bāzē - RAKUS klīnikā "Gaiḷezers" (vadītāja profesore G. Krūmiņa). Evakuēto cerebrālo metastāžu ǵenētiskā analīze veikta sadarbībā ar Rīgas Stradiṇa universitātes Onkologijas institūtu (vadītājs - profesors E. Miklaševičs).

Darba zinātniskā vadītāja:

Dr. med. docente Daina Apškalne, Rīgas Stradiṇa universitāte, Latvija

Oficiālie recenzenti:

Dr. med. asociētā profesore Gunta Purkalne, Rīgas Stradiņa universitāte, Latvija

Dr. med. Juris Dzenis, Latvijas Universitāte

Dr. med. asociētais profesors Saulius Rocka,

Viḷnas universitāte, Lietuva

Promocijas darba aizstāvēšana notiks 2015. gada 10. jūnijā plkst. 15.00 Rīgas Stradiṇa universitātes Medicīnas promocijas padomes atklātā sēdē Rīgā, Dzirciema ielā 16, Hipokrāta auditorijā.

Ar promocijas darbu var iepazīties RSU bibliotēkā un RSU mājas lapā: www.rsu.lv

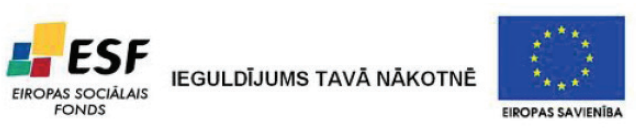

Promocijas darbs veikts ar Eiropas sociālā fonda projekta "Atbalsts doktorantiem studiju programmas apguvei un zinātniskā grāda ieguvei Rīgas Stradiņa universitātē” finansiālu atbalstu.

Promocijas padomes sekretārs:

Dr. med. docents Arvīds Irmejs 


\section{SATURS}

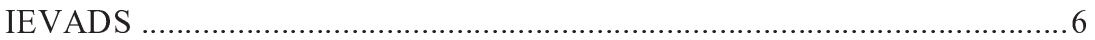

1. MATERIĀLS UN METODES .......................................................... 13

1.1. Ķirurğiski ārstēto un kompleksu terapiju saņēmušo pacientu

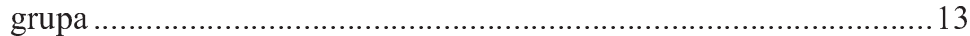

1.1.1. Pètījuma populācija .......................................................... 13

1.1.2. Pētījuma grupas pacientu anketas raksturojums ...................... 14

1.2. Radioķirurǵiski ārstēto pacientu grupa........................................... 16

1.2.1. Pētījuma populācija ........................................................ 16

1.2.2. Pētījuma grupas pacientu anketas raksturojums ...................... 16

1.2.3. Radioķirurgijas pielietojuma apraksts .................................... 17

1.2.4. Radioķirurğijas izpildes kvalitātes nodrošināšana .................... 18

1.3. Histoloğiskā materiāla g̊enētiskā analīze ...................................... 19

1.3.1. DNS izdalīšana no formalīnā fiksētiem un parafīnā

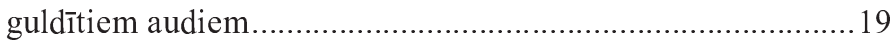

1.3.2. RL-PĶR/AIK analīze TP53 gēna 5.-8. eksonu mutāciju noteikšanai....................................................... 19

1.3.3. TP53 gēna 5.-8. eksonu sekvencēšana .................................... 21

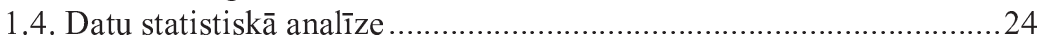

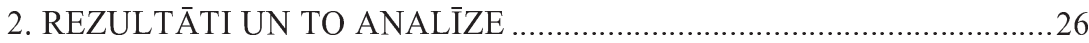

2.1. Rezultāti un to analīze ķirurğiski ārstēto un kompleksu terapiju

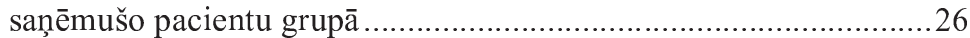

2.1.1. Pacientu grupas raksturojums ........................................... 26

2.1.2. Ķirurğ́iskā pieeja un metastāžu evakuācijas apjoms .................28

2.1.3. Perioperatīvas komplikācijas ..................................................29

2.1.4. Pēcoperācijas pacientu klīniskā stāvokḷa izvērtējums

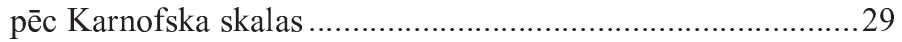

2.1.5. Postoperatīvās dzīvildzes rādītāji un to ietekmējošo faktoru

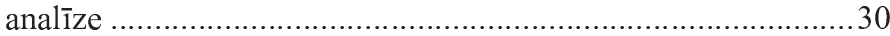

2.1.5.1. Pēcoperācijas dzīvildzi ietekmējošo faktoru vienvariantu analīze ............................................. 32

2.1.5.2. Pēcoperācijas dzīvildzi ietekmējošo faktoru

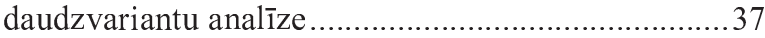

2.1.6. Ķirurğiski ārstēto un kompleksu terapiju sañēmušo pacientu grupu 1., 2., 3. un 4. protokola ārstēšanas gaita un rezultāti....38

2.2. Rezultāti radioķirurgíski ārstēto pacientu grupā..............................40

2.3. Cerebrālo metastāžu TP53 gēna analīzes rezultāti .............................45

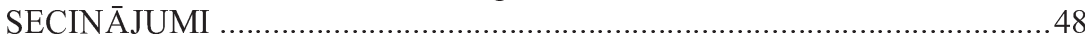

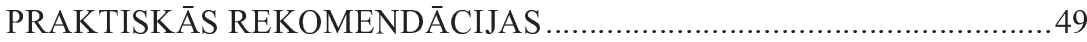




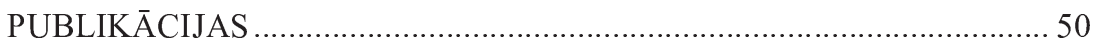

TĒZES UN UZSTĀŠANĀS STARPTAUTISKĀS KONFERENCĒS ........ 51

TĒZES UN UZSTĀŠANĀS KONFERENCĒS LATVIJĀ ….................... 52

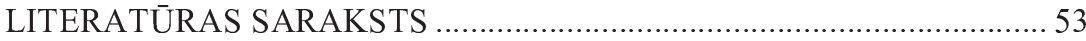

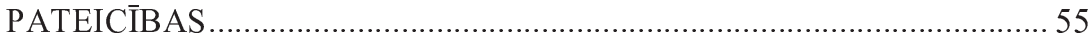




\section{DARBĀ LIETOTIE SAĪSINĀJUMI}

\begin{tabular}{|c|c|c|}
\hline Saīsinājums & Skaidrojums angḷu valodā & Skaidrojums latviešu valodā \\
\hline $\mathrm{CH}$ & Chemotherapy & Ķīmijterapija \\
\hline CT & Computerized Tomography & Datortomogrāfijas izmeklējums \\
\hline DS-GPA & $\begin{array}{l}\text { Diagnosis - specific graded } \\
\text { prognostic assessment }\end{array}$ & $\begin{array}{l}\text { Diagnozei specifisks gradēts } \\
\text { prognostisks novērtējums }\end{array}$ \\
\hline FSRT & $\begin{array}{l}\text { Fractionated Stereotactic } \\
\text { Radiotherapy }\end{array}$ & $\begin{array}{l}\text { Frakcionēta stereotaktiska staru } \\
\text { terapija }\end{array}$ \\
\hline GPA & Graded prognostic assessment & $\begin{array}{l}\text { Gradēts prognostisks } \\
\text { novērtējums }\end{array}$ \\
\hline GY & Gray & Grejs \\
\hline IGRS & Image-guided radiosurgery & Attēlvadīta radioksirurgíja \\
\hline KPS & Karnofsky performance scale & Karnofska veiktspējas skala \\
\hline MRI & Magnetic Resonance Imaging & $\begin{array}{l}\text { Magnētiskās rezonanses } \\
\text { izmeklējums }\end{array}$ \\
\hline MTS & Metastasis & Metastāze \\
\hline PKSR & Polymerase chain reaction & Polimerāzes ksēdes reakcija \\
\hline RPA & Recursive partitioning analysis & Rekursīva sadalījuma analīze \\
\hline RT & Radiotherapy & Staru terapija \\
\hline RTOG & $\begin{array}{l}\text { Radiation Therapy Oncology } \\
\text { Group }\end{array}$ & Staru terapijas onkologijas grupa \\
\hline SRS & Stereotactic radiosurgery & Stereotaktiska radioksirurgija \\
\hline TU & Tumor & Audzējs \\
\hline WBRT & Whole-brain radiation therapy & $\begin{array}{l}\text { Visu galvas smadzeņu } \\
\text { apstarošana }\end{array}$ \\
\hline
\end{tabular}




\section{IEVADS}

Metastāzes galvas smadzenēs ir visbiežāk sastopamā intrakraniālo audzēju forma, kas rodas 10-40\% visu vēža slimnieku (7; 15). Smadzeņu metastāžu diagnosticēšanas incidencei ir tendence pieaugt, jo kḷuvusi pieejama kvalitatīvi uzlabota diagnostikas aparatūra (daudzslāņu datortomogrāfija un magnētiskā rezonanse), kā arī pagarinās vēža pacientu dzīvildze sakarā ar uzlabojumiem pamatslimības kontrolē un ārstēšanā (16). Metastātisko galvas smadzeņu audzēju grupā pirmo vietu ieņem elpošanas orgānu audzēji (20\%), tālāk seko krūts vēzis (15\%) un melanoma (10\%) (3); no tiem melanomai raksturīga visbiežākā izpausme vairāku cerebrālu metastāžu veidā (14). Atbilstoši literatūras datiem lielam vēža slimnieku skaitam (21-86\%) attīstīsies vairākas cerebrālas metastāzes $(3 ; 13)$.

Diemžēl pacientam šî diagnoze saistās ar sliktāku prognozi gan attiecībā uz paredzamo dzīvildzi, gan arī no dzīves kvalitātes viedokḷa. No tā brīža, kopš diagnosticēta cerebrāla metastāze, ja netiek pielietota ārstēšana, pacienti mirst tuvāko mēnešu laikā, progresējot pamatslimībai vai neirologiiskajiem simptomiem. Vidējās dzīvildzes prognoze pacientiem ar vairākām cerebrālām metastāzēm parasti ir slikta (2,3-7,1 mēneši), un pielietotās paliatīvās terapijas mērķis ir nodrošināt iespējami optimālu dzīves kvalitāti (17). Vēža diagnozes noteikšanas laikā metastāzes smadzenēs ir arvien biežāks saslimstības un mirstības, kā arī kognitīvo traucējumu iemesls $(2 ; 10)$.

Ilgstoši bija izplatīts uzskats, ka diagnoze ,cerebrālas metastāzes” nozīmē terminālu vēža stadiju, un tālākais ārsta uzdevums ir tikai nodrošināt pacientam adekvātu paliatīvu ārstēšanu. Onkologam bija problemātiski ieteikt terapiju, ņemot vērā faktu, ka vairums ķ̄imijterapijas preparātu nevar šķērsot hematoencefālo barjeru. Neiroķirurgi šādā gadījumā, visdrīzāk, operēja tikai solitāru, ķirurǵiski viegli pieejamu, simptomātisku metastāzi, bet staru terapeiti 
ordinēja paliatīvu visu galvas smadzeņu apstarošanu, tādējādi veidojās jaunas metastāzes un saslimšana turpināja progresēt.

Taču, kḷūstot pieejamām jaunām tehnologijāam, cerebrālu metastāžu ārstēšanā vērojams straujš progress. Arī Latvijā, uzlabojoties neiroķirurğiskajiem instrumentiem un operācijas plānošanas un veikšanas ierīcēm, un no 2010. gada kḷūstot pieejamam bezrāmja, attēlvadītam stereotaktiskās radioķirurğijas aprīkojumam, ir visi nosacījumi tam, lai cerebrālo metastāžu slimniekiem varētu nodrošināt mūsdienīgu kompleksu ārstēšanu.

Mūsu pētījumā tika iekḷauta nodaļa par 40 ķirurğisku un kompleksu terapiju saņēmušiem divu un vairāku cerebrālu metastāžu pacientiem, kā arī par pirmajiem 16 Latvijā radioķirurgiski ārstētajiem pacientiem ar vienu un vairākām cerebrālām metastāzēm. Jāuzsver, ka arī vienas metastāzes radioķirurğiskas ārstēšanas rezultāti ir ļoti būtiski pacientiem ar divām un vairākām metastāzēm, jo, pielietojot radioķirurg̣isku ārstēšanu, svarīgāks par metastāžu skaitu ir ārstētās patoloǵijas kopējais tilpums (piemēram, līdzvērtīgi tilpuma rādītāji var būt divām mazām un vienai lielai metastāzei), un gadījumos, kad pacientam ar divām vai vairākām metastāzēm ķirurğiski neizdodas evakuēt visus mezglus, tālākai radioķirurǵiskai terapijai var pakļaut vienu vai vairākas no atlikušajām cerebrālajām metastāzēm.

Jāpiemin arī, ka labāki prognostiskie parametri var būt nozīmīgi, izvēloties vispiemērotākos ārstēšanas veidus. 1997. gadā Radiation Therapy Oncology Group (RTOG) publicēja rekursīva sadalījuma analīzes (RPA) (statistiska metode pacientu klasificēšanai) rezultātus par pacientiem ar metastāzēm galvas smadzenēs, iedalot pacientus trijās prognostiskās grupās un šo grupējumu pamatojot ar tādiem main̄̄gajiem parametriem kā vecums, KPS rādītāji un ekstrakraniālās slimības smagums (6). 2008. gadā $R P A$ klasifikācija vispārējā onkologijāa tika papildināta ar vairākiem citiem faktoriem un izveidota 
GPA (graded prognostic assessment) (18) klasifikācija. Tās pamatā ir RPA klasifikācija, kas tika papildināta ar vairākiem kritērijiem, kuri precīzāk ļauj noteikt pacienta iespējamo prognozi. GPA sistēma ir līdzvērtīga $R P A$ sistēmai, bet tā ir mazāk subjektīva un vieglāk lietojama. Papildus pamatkritērijiem šeit tiek ņemts vērā arī diagnosticēto cerebrālo metastāžu skaits, pieņemot, ka pacienti ar 1-3 metastāzēm dzīvo ilgāk, nekā pacienti ar multiplu metastāžu disemināciju. Atbilstoši GPA tiek novērtēts pacienta vecums, KPS rādītāji, ekstrakraniālu metastāžu klātiene un metastāžu skaits (viena, divas, trīs un vairāk nekā trīs). Turklāt pavisam nesen - 2010. gadā - ir izstrādāta diagnozei specifiska GPA klasifikācija (DS-GPA) (19), kas l̦auj individualizēt paredzamās dzīvildzes prognozēšanu. Tas sadala šos faktorus, papildus ņemot vērā histoloǵisko metastāzes diagnozi. Tā, piemēram, sīkšūnu plaušu vēža un nesīkšūnu plaušu vēža prognostiskie faktori ietver 4 faktorus, turpretī krūšu un gastrointestinālā vēža vienīgais būtiskais faktors ir KPS rādītāji. Jāpiemin, ka arī šai sistēmai ir trūkumi, - kā piemēru minot pacientu grupu, kurā primārais audzējs nav zināms. Tas nozīmēe, ka tuvākās nākotnes jautājums ir šīs prognostiskās sistēmas uzlabošana, pilnveidošana un ieviešana klīniskajā praksēe, lai, pirms galīga lēmuma pieņemšanas par to, cik radikāla būtu pacientam piedāvātā ārstēšanas izvēle, lēmums būtu individuāls un tiktu balstīts uz daudzu faktoru kopumu.

Nelielā skaitā literatūras avotu ir pieejami dati par to, ka evakuēto cerebrālo metastāžu histologiskā materiāla ǵenētiskās analīzes informācija var būt noderīga pēcoperācijas dzīvildzes prognozei $(4 ; 11 ; 12)$. TP53 ir tumoru supresijas gēns, un mutācijas šajā gēnā izraisa audzēja supresijas spējas zudumu. Lai gan ir pagājuši vairāk nekā 20 gadu kopš tika atklātas pirmās TP53 gēna mutācijas, tomēr tā statusa novērtējums nenodrošina skaidras tā klīniskā pielietojuma indikācijas. Lielākās grūtības rada plašā mutāciju un metodologisko pieeju heterogenitāte mutāciju izvērtēšanā, nav pieejami arī 
vienoti kritēriji TP53 gēna statusa novērtěšanā attiecībā uz diagnozi un prognozi. Mūsu pētījuma ietvaros pirmo reizi Latvijā tika veikta ķirurǵiski evakuēto cerebrālo metastāžu genētiskā materiāla izvērtēšana klīniski nozīmīgu TP53 gēna mutāciju konstatācijai, kā arī iegūto datu analīze.

Mūsu veiktais pētījums (iekļauti 40 pacienti) devis nozīmīgu ieguldījumu divu un vairāku cerebrālo metastāžu ārstēšanas metožu izstrādē, jo, ņemot vērā divu un vairāku cerebrālo metastāžu ķirurgisiskas ārstēšanas augsto sarežğītības pakāpi un slikto dzīvildzes prognozi, pasaules vadošajos literatūras izdevumos apkopotajos pētījumos pārsvarā iekļauts neliels pacientu skaits. Parasti tie ir 30-60 pētījumā iekḷauti ķirurğiski ārstēti pacienti ar divām un vairākām cerebrālām metastāzēm $(1 ; 5 ; 8 ; 9)$.

Mūsdienīga pieeja cerebrālu metastāžu ārstēšanā ir vērsta uz pieejamo ārstēšanas metožu (ķirurğiska terapija, radioterapija un ķīmijterapija) adekvātu kombināciju, lai nodrošinātu pacientu dzīves kvalitātes, funkcionalitātes saglabāšanu un dzīvildzes pagarināšanu. Pēdējo divdesmit gadu laikā pasaules literatūrā ir ieteiktas daudzas vadlīnijas un protokoli multidisciplinārai cerebrālu metastāžu ārstēšanas pieejai, taču joprojām lēmumu pieņemšana klīniskajā praksē ir saistīta ar neatbildētiem jautājumiem. Tādēl nepieciešama turpmāka pētījumu veikšana un rezultātu apkopošana, jo īpaši pacientiem ar divām un vairākām cerebrālām metastāzēm.

\section{Promocijas darba struktūra}

Promocijas darbs uzrakstīts latviešu valodā. Promocijas darbam ir šādas sadaļas: ievads, literatūras apskats, materiāli un metodes, rezultāti, diskusija, secinājumi un izmantotā literatūra. Zinātniskā darba kopējais apjoms ir 116 lappuses; tajā iekḷautas 16 tabulas un 43 attēli. 


\section{Darba mērksis}

Savstarpēji salīdzināt un statistiski izanalizēt divu un vairāku galvas smadzeņu metastāžu ķirurğiskas un kombinētas ārstēšanas iespējas un rezultātus, kā arī izvērtēt pirmos galvas smadzeņu metastāžu radioķirurğiskas ārstēšanas rezultātus Latvijā.

\section{Darba uzdevumi}

1. Apkopot divu un vairāku galvas smadzeņu metastāžu ķirurğiskās ārstēšanas taktiku un rezultātus.

2. Novērtēt dažādu faktoru ietekmi uz pēcoperācijas dzīvildzes garumu.

3. Izvērtēt dzīvildzes rādītāju atšksirības, veicot radikālu vai parciālu galvas smadzeņu metastāžu evakuāciju.

4. Izanalizēt ārstēšanas rezultātus pacientiem, kuriem tika veikta parciāla galvas smadzeņu metastāžu evakuācija ar pielietotu kompleksu terapiju (WBRT vai $W B R T$ un ķīmijterapiju) pēcoperācijas periodā.

5. Izvērtēt galvas smadzeņu metastāžu radioķirurǵiskas ārstēšanas pirmos rezultātus Latvijā.

6. Identificēt klīniski nozīmīgas TP53 gēna mutācijas cerebrālās metastāzēs un noteikt to saistību ar pēcoperācijas dzīvildzi.

\section{Darba hipotēzes}

1. Divu un vairāku galvas smadzeņu metastāžu ārstēšanas rezultāti korelē ar veiktās ķirurǵiskās manipulācijas radikalitāti.

2. Ķirurgiska divu un vairāku galvas smadzeņu metastāžu evakuācija nav saistīta ar paaugstinātu pēcoperācijas morbiditāti un mortalitāti. 
3. Mērķtiecīgas kombinētas terapijas pielietojums saglabā pacientu funkcionalitāti un pagarina dz̄̄vildzi pacientiem ar divām un vairākām smadzeņu metastāzēm arī pēc metastāžu daļējas evakuācijas.

4. Radioķirurğiskas staru terapijas pielietojumam nelielu (līdz $3 \mathrm{~cm}$ diametrā) galvas smadzeņu metastāžu terapijā ir pozitīvs efekts.

\section{Pētījuma aktualitāte, novitāte un praktiskā nozīme}

1. Apkopoti un analizēti ārstēšanas rezultāti tiem pacientiem ar divām un vairākām cerebrālām metastāzēm, kuriem veikta metastāžu ķirurǵiska un kompleksa ārstēšana.

2. Apkopoti un analizēti ārstēšanas rezultāti pirmajiem 16 Latvijā radioķirurğiski ārstētajiem cerebrālo metastāžu pacientiem.

3. Precizēti pēcoperācijas dz̄ivildzes prognostiskie parametri pacientiem, kuriem ir divas un vairākas cerebrālas metastāzes.

4. Pētījuma ietvaros pirmo reizi Latvijā tika veikta ķirurgisiski evakuēto cerebrālo metastāžu ǵenētiskā materiāla izvērtēšana klīniski nozīmīgu TP53 gēna mutāciju konstatācijai, kā arī iegūto datu analīze.

5. Izstrādāti ieteikumi to slimnieku pielietojamās terapijas taktikas izvēlei, kuriem konstatētas divas un vairākas cerebrālas metastāzes.

\section{Personīgais ieguldījums}

Darba autors ir patstāvīgi apkopojis informāciju par pētījumā iekḷautajiem pacientiem, aizpildot speciāli pētījumam izstrādātu anketu, kā arī apkopojis, sistematizējis un analizējis pacientu klīniskos datus, izmantojot medicīnisko dokumentāciju. 
Divu un vairāku cerebrālu metastāžu ķirurǵiskajā ārstēšanas etapā autors bijis operācijas veicējs vai asistents. Autors piedalījies arī kompleksas terapijas plānošanā un slimnieku simptomātiskās terapijas un novērošanas veikšanā. 


\section{MATERIĀLS UN METODES}

\section{1. Ķirurğiski ārstēto un kompleksu terapiju saṇēmušo pacientu grupa}

\subsubsection{Pētījuma populācija}

Retrospektīva (2005.-2011.) Rīgas Austrumu klīniskās universitātes slimnīcas klīnikas „Gailiezers” operēto divu un vairāku cerebrālo metastāžu slimnieku slimības vēsturu analīze.

Ieklaušanas kritēriji pacientu dalībai pētījumā bija šādi:

- diagnosticētas divas vai vairākas cerebrālas metastāzes;

- veikta ķirurǵiska visu cerebrālo metastāžu mezglu vai daḷēja cerebrālo metastāžu mezglu evakuācija;

- preoperatīvi pacienta klīniskais stāvoklis pēc Karnofska skalas $\geq 60$ ballēm;

- $\quad$ pacienta vecums $-\geq 18$ gadiem;

- veikta maksimāli iespējama izmeklēšana primārā audzēja diagnosticēšanai un izvērtēšanai;

- histoloǵiski apstiprināta cerebrālās metastāzes diagnoze;

- pieejama informācija par pēcoperācijas dzīvildzes garumu;

- pieejami dati par veiktas postoperatīvas kompleksas terapijas gaitu un rezultātiem;

- pieejami evakuēto cerebrālo metastāžu histoloǵiskie preparāti ǵenētiskās analīzes veikšanai.

Pacienta dzimumam, primārajam audzējam un iegūtajai histoloǵiskajai diagnozei nebija nozīmes iekḷaušanas kritēriju izvirzīšanā. 
Izslēgšanas kritēriji pacientu dalībai pētījumā bija šādi:

- preoperatīvi pacienta klīniskais stāvoklis pēc Karnofska skalas $<60$ ballēm;

- metastāzes lokalizācija galvas smadzeņu stumbra rajonā;

- blakusslimības, kas nel̦auj veikt ķirurǵisku un kombinētu terapiju atbilstoši plānotajam protokolam;

- karcinomatoza meningeāla procesa diseminācija.

Pacienti tika ārstēti saskaņā ar turpmāk minētajiem protokoliem:

$\checkmark$ 1. protokols. Tikai ķirurğiska visu diagnosticēto cerebrālo metastāžu evakuācija;

$\checkmark$ 2. protokols. Tikai ķirurğiska, dal̦ēja simptomātisko cerebrālo metastāžu evakuācija;

$\checkmark$ 3. protokols. Daḷēja ķirurǵiska simptomātisko metastāžu evakuācija un visu galvas smadzen̦u apstarošana (WBRT);

$\checkmark$ 4. protokols. Daḷēja ķirurğiska simptomātisko metastāžu evakuācija, visu galvas smadzeņu apstarošana (WBRT) un ķīmijterapija.

\subsubsection{Pētījuma grupas pacientu anketas raksturojums}

Tika izveidota datubāze, kurā tika apkopoti katra slimnieka turpmāk minētie parametri: vecums, dzimums, primārās saslimšanas veids, diagnosticēto cerebrālo metastāžu skaits, pamatslimības kontrole, cerebrālo metastāžu prezentācija (metahroni / sinhroni), kraniotomiju skaits un veids, ķirurǵiskās evakuācijas apjoms, pēcoperācijas komplikācijas, pēcoperācijas periodā saņemtā staru terapija un ķīmijterapija, pēcoperācijas dzīvildzes rādīiāji katram pacientam.

Pacientu funkcionālo stāvokli iestāšanās laikā stacionārā un izrakstīšanās laikā no tā izvērtēja, izmantojot Karnofska skalu (KPS). 
Visi pacienti pēc Gaspar et al. atbilstoši tika sadalīti RTOG RPA (Radiation Therapy Oncology Group recursive partitioning analysis) klasēs: I klase - pacienti, kuru klīniskais stāvoklis pēc Karnofska skalas atbilst vismaz 70 ballēm un kuri ir jaunāki par 65 gadiem, ar kontrolētu pamatslimību un metastāzēm tikai galvas smadzenēs; II klase - pacienti, kuru klīniskais stāvoklis pēc Karnofska skalas atbilst vismaz 70 ballēm, bet kuri ir vai nu vecāki par 65 gadiem vai ar nekontrolētu pamatslimību vai arī ar metastāzēm ne tikai smadzenēs, bet arī citos orgānos; III klase - pacienti, kuru klīniskais stāvoklis pēc Karnofska skalas atbilst mazāk par 70 ballēm.

Laika periodā no 2005. līdz 2011. gadam visi pacienti tika operēti plānveida kārtā un perioperatīvi saņēma antibiotikas, antikonvulsantus un steroīdus. Visās operācijās tika pielietotas šādas metodes:

1) neironavigācija, lai nodrošinātu precīzu pieeju metastāzei un atvieglotu tās intraoperatīvu lokalizēšanu un saudzīgu un direktu pieeju;

2) kavitrona ultraskaņas aspirācijas sistēma metastāzes tilpuma samazināšanai, kas atviegloja metastāzes rezekciju „en block” manierē;

3) operācijas mikroskops gadījumos, kad metastāzes lokalizējās subkortikāli vai paramediāni.

Tika izvērtētas un reǵistrētas pēcoperācijas komplikācijas. Nāves iestāšanās 30 dienu laikā pēc operācijas tika uzskatīta par perioperatīvu mortalitāti. Pirms operācijas un izrakstǐšanās laikā no stacionāra tika reǵistrēts pacienta klīniskais stāvoklis pēc Karnofska skalas.

Pēcoperācijas dzīvildzes rādītāju izvērtēšanai tika izmantoti pieejamie iedzīvotāju reǵistra dati (dzīvildze tika aprēķināta no operācijas veikšanas brǐža līdz pētījuma pabeigšanas brīdim vai nāves iestāšanās datumam). 


\subsection{Radioķirurğiski ārstēto pacientu grupa}

\subsubsection{Pētījuma populācija}

Retrospektīva (2010.-2012.) Rīgas Austrumu klīniskās universitātes slimnīcas Latvijas Onkolog̣ijas centra Terapeitiskās radiologijas un medicīnas fizikas klīnikas radioķirurgíisku terapiju saṇēmušo cerebrālo metastāžu slimnieku slimības vēsturu analīze.

\subsubsection{Pētījuma grupas pacientu anketas raksturojums}

Tika izveidota datubāze, kurā tika apkopoti turpmāk minētie katra slimnieka parametri: vecums, dzimums, primārās saslimšanas veids, slimnieka klīniskais stāvoklis pēc Karnofska skalas, diagnosticēto cerebrālo metastāžu skaits, saņemtā radioķirurğiskā terapija vai frakcionētā radioķirurğiskā ārstēšana kombinācijā ar vai bez visu galvas smadzeņu apstarošanas, staru devas tilpums un robežas.

Plānotais radioḳirurğiskajā ārstēšanā lietojamais mērḳa tilpums tika aprēķināts, izmantojot GammaPlan programmu. Summārais paredzamā mērķa ārstēšanas tilpums katram pacientam bija skaitlis, ko veidoja saskaitītas katras atsevišşas staru terapiju saņēmušās metastāzes tilpumu summa.

Pēc pielietotās ārstēšanas pacienti tika novēroti ar magnētiskās rezonanses kontrastizmeklējumiem 6-8 nedēḷas pēc radioķirurğiskās ārstēšanas pārtraukšanas un pēc tam katrus nākamos 3 mēnešus līdz pētījuma beigām vai pacienta nāvei.

Par pielietotās stereotaktiskās radioķirurğijas efektivitāti tika definēti ārstēto cerebrālo metastāžu magnētiskās rezonanses izmeklējumu rezultāti, un tie tika iedalīti turpmāk minētajās četrās grupās: 
1) veidojuma rezorbcija (VR) - piln̄̄ga kontrastvielu krājošas metastāzes mezgla uzsūkšanās;

2) metastāzes daļēja rezorbcija (DR) - kontrastvielu krājošas metastāzes mezgla izmēru samazināšanās $>50 \%$;

3) kontrolēta saslimšana (KS) - kontrastvielu krājošas metastāzes dimensionāla nemainība vai izmēru samazināšanās $<50 \%$;

4) metastāzes progresija (MP) - kontrastvielu krājošas metastāzes izmēru palielināšanās $>25 \%$.

Pēc saṇemtās radioḳirurğiskās ārstēšanas dzivildzes rādītāju izvērtēšanai tika izmantoti pieejamie iedzīvotāju reǵistra dati (dz̄ivildze tika aprēķināta no radioķirurğiskās ārstēšanas veikšanas brīža līdz pētījuma pabeigšanas brīdim vai nāves iestāšanās datumam).

\subsubsection{Radioķirurğijas pielietojuma apraksts}

Datortomogrāfijas (DT) un terapijas laikā pacienti tika imobilizēti, izmantojot Brain $L A B$ neinvazīvo stereotaktisko imobilizācijas maskas sistēmu.

Bija pieejams katra pacienta magnētiskās rezonanses tomogrāfijas $(M R T)$ attēls, lai varētu noskaidrot mērķa tilpumu. Audzēju iezīmēja ar $M R T$ attēla palīdzību, un pēc tam tika veikta kopīga $D T$ un $M R T$ attēlu reǵistrācija, lai pārnestu mērķa tilpumu uz DT attēliem, ko izmantoja devas aprēķinam. Klīnisko mērķa tilpumu (CTV) definēja kā summāro mērķa tilpumu (GTV) apkopojumu, iezīmētu $M R T$ attēlos, kā arī DT attēlos. Subklīniskam paplašinājumam netika pievienotas noteiktas robežas. Plānotā mērķa tilpuma $(P T V)$ robeža visos virzienos bija $1 \mathrm{~mm}$, tā pievienota $C T V$.

Stereotaktiskā radioķirurğija (SRS) tika plānota ar Eclipse ${ }^{\mathrm{TM}}$ (Varian Medical Systems INC, USA) terapijas plānošanas sistēmu (TPS), izmantojot volumetrisko intensitātes modulēto devas ievadīšanu ar $\operatorname{RapidArc}^{\mathrm{TM}}$ 
(Varian Medical Systems INC, USA) vai intensitātes modulēto staru terapiju (IMRT) ar 7-9 intensitātes modulētiem terapijas laukiem. Ārstēšanas plāns tika normalizēts līdz 80\% izodevas līnijai, un normalizētā 100\% izodevas līnija ietvēra PTV. SRS veikšanai tika izmantots lineārais paātrinātājs NovalisTx $^{\mathrm{TM}}$, kas aprīkots ar augstas izşkirtspējas daudzplātņu kolimatoru (MLC 120HD). Visi plāni tika ievadīti, izmantojot fotonu enerǵiju $6 \mathrm{MV}$ un devas ātrumu 1000 monitora vienību $(M U)$ minūtē. Pacienta novietojuma korig̣ēšanai tika izmantota ExacTrac ${ }^{\circledR}$ 6D (3 transversālu virzienu un 3 rotāciju) IGRT (ImageGuided Radiotherapy; apstarošana pēc attēla) sistēma (BrainLAB GMBH, Munich, Germany).

\subsubsection{Radioḳirurǵijas izpildes kvalitātes nodrošināšana}

Visi ārstēšanas plāni no dozimetriskā viedokḷa tika apstiprināti kompleksā verifikācijas procedūrā, kas ietvēra devas plaknes mērījumus un punkta devas mērījumus fantomā un Winston-Lutz testā. Devas plaknes mērījumus veica, izmantojot Gafchromic EBT2 filmiņas beigu novērtējumā iesaistîtā gamma indeksa metodi. Kopumā rezultātus uzskatīja par pieņemamiem, ja vairāk nekā 90\% novērtēto punktu atbilda gamma kritērijiem $1 \mathrm{~mm} / 5 \%$. Punktu devas mērījumus veica, izmantojot precīzo 3D (PTW, Freiburg, Germany) jonizācijas kameru. Punktu devas mērījumu tolerances līmeni noteica 3\% intervālā. Ārstēšanas vienību uzskatīja par atbilstošu terapijas veikšanai, ja izocentra lauks, kas noteikts Winston-Lutz testā, nepārsniedza $1 \mathrm{~mm}$. 


\subsection{Histoloğiskā materiāla ǵenētiskā analīze}

\subsubsection{DNS izdalīšana no formalīnā fiksētiem un parafīnā guldītiem audiem}

DNS izolēšanai no formalīnā fiksētiem un parafīnā guldītiem audiem izmantoja DNS reaǵentu komplektu (QIAamp DNA FFPE Tissue Kit, Qiagen, Vācija) saskaņā ar ražotāja instrukciju.

\subsubsection{RL-PĶR/AIK analīze TP53 gēna 5.-8. eksonu mutāciju noteikšanai}

1.3.2.1. tabula

Praimeri polimerāzes k̦ēdes reakcijai (PĶR)

\begin{tabular}{|l|l|c|c|}
\hline Gēns & \multicolumn{1}{|c|}{ Praimeris } & Eksons & Hibr. temp., ${ }^{\circ} \mathbf{C}$ \\
\hline TP53 & CAACTCTGTCTCCTTCCTCTTCCTAC & 5 A & 58 \\
\hline & AGCCATGGCACGGACGCG & 58 \\
\hline & CTCCTGCCCGGCACCCGC & 5 B & 58 \\
\hline & CTAAGAGCAATCAGTGAGGAATCAGA & 58 \\
\hline & CAACCACCCTTAACCCCTCCT & 6 & 58 \\
\hline & AGACGACAGGGCTGGTTGC & 7 & 58 \\
\hline & AGGCGCACTGGCCTCATC & & 58 \\
\hline & GAGGCTGATTTCCTTACTGCCTCTTG & & 58 \\
\hline
\end{tabular}


Izmeklēšanas procedūras gaita aprakstīta turpmāk minēto darbību veikšanas secībā.

Praimeri PĶR reakcijai. Vienai reakcijai nepieciešams viens praimeru pāris, kas amplificē PĶR produktu, kurš satur TP53 gēna eksonu un daļu introna un splaisinga vietu.

Katru paraugu sagatavo tripletā, lai izslēgtu pilināšanas kḷūdu un analīze būtu precīzāka.

Nepieciešamos reaǵentus pirms procedūras uzsākšanas izņem no saldētavas un atkausē. Ja nepieciešams, reaǵentus centrifugē, nodrošinot to optimālu izlietojumu.

Sagatavo PĶR maisījumu (sastāvs norādīts vienai reakcijai):
$10 \times P C R$ buferšķīdums
$2 \mu \mathrm{l} ;$
$10 \mathrm{mM} d N T P$ maisījums
$0,4 \mu \mathrm{l}$
$50 \mathrm{mM} \mathrm{MgCl} 2$
$0,4 \mu \mathrm{l}$;
praimeris 1
$0,4 \mu \mathrm{l}$;
praimeris 2
$0,4 \mu \mathrm{l}$;
Syto 9
$2 \mu \mathrm{l}$;
DNS
$10 \mathrm{ng}$;

Taq polimerāze Speed Star

$0,5 \mathrm{U}$;

$\mathrm{H}_{2} \mathrm{O}$

līdz $20 \mu \mathrm{l}$;

Sagatavoto PĶR maisījumu izkliedē $0,2 \mathrm{ml}$ mēgenēs̄s vai arī ierīces Rotor-Gene 6000 pielāgotos diskos, kas noslēdzami ar termiski pielīmējamu plēvi.

Ierīces Rotor-Gene 6000 disku ievieto diska turētājā un uzliek diska fiksējošo gredzenu. 
Ieslēdz datoru un PĶR reālā laika noteikšanas ierīci CorbettResearch 6000.

Aktivizē programmu Rotor-gene 6000 Series Software 1.7.

Ieslēdz programmā ikonu „New run”:

$\begin{array}{ll}95{ }^{\circ} \mathrm{C} & 10 \text { sekundes } \\ 65{ }^{\circ} \mathrm{C} & 5 \text { sekundes } \\ 72{ }^{\circ} \mathrm{C} & 20 \text { sekundes } \\ 95{ }^{\circ} \mathrm{C} & 1 \text { sekunde } \\ 72{ }^{\circ} \mathrm{C} & 1 \text { minūte }\end{array}$
AIK
$72-86{ }^{\circ} \mathrm{C}$
2 sekundes uz soli
$0,1 \%$ solī

\subsubsection{TP53 gēna 5.-8. eksonu sekvenēšana}

Izmeklēšanas procedūras gaita aprakstīta turpmāk minēto darbību veikšanas secībā.

Polimerāzes ķēdes reakcijas ( $P C R$ jeb PĶR) fragmenta sagatavošana sekvenēšanas reakcijai.

Praimeri PĶR reakcijai norādīti 1.3.2.1. tabulā. Vienai reakcijai nepieciešams viens praimeru pāris, kas amplificē PĶR produktu, kurš satur vienu vai vairākus eksonus un dalıu introna un splaisinga vietu.

Sagatavo PĶR maisījumu (sastāvs norādīts vienai reakcijai):

$\begin{array}{ll}10 \times \text { PCR buferšķ̄ìums } & 5 \mu \mathrm{l} \\ 10 \mathrm{mM} \text { dNTP maisījums } & 0,5 \mu \mathrm{l} \\ \text { praimeris 1 } & 1 \mu \mathrm{l} \\ \text { praimeris 2 } & 1 \mu \mathrm{l}\end{array}$


DNS

Taq polimerāze

$\mathrm{H}_{2} \mathrm{O}$
$50 \mathrm{ng}$

$1 \mathrm{U}$

līdz $50 \mu 1$

PĶR maisījumu pa $50 \mu$ izkliedē vienā PĶR platē un aiztaisa ar plates plēvi.

PĶR plati ievieto ciklerā un izvēlas turpmāk minēto programmu:

$95{ }^{\circ} \mathrm{C} \quad 5$ minūtes

$95{ }^{\circ} \mathrm{C} \quad 30$ sekundes

$58{ }^{\circ} \mathrm{C} * \quad 45$ sekundes

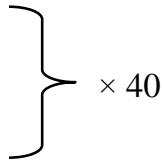

$72{ }^{\circ} \mathrm{C} \quad 40$ sekundes

$72{ }^{\circ} \mathrm{C} \quad 3$ minūtes

$40{ }^{\circ} \mathrm{C} \quad$ pauze

* Hibridizācijas temperatūras dažādiem praimeru pāriem parādītas 2.1.1. tabulā.

PĶR fragmentu attīrī̌anai izmanto MinElute 96UF PCR Purification Kit, ievērojot ražotāja instrukcijas.

Pēc paraugu attīrīšanas tiek mērīta koncentrācija ar NanoDrop 1000 spektrofotometru. Paraugu koncentrācijai pēc attīrīšanas jābūt $5 \mathrm{ng} / \mu \mathrm{l}$. Vienai sekvenēšanas reakcijai nepieciešams 7,5 ng PĶR produkta. Ja koncentrācija ir lielāka kā nepieciešams, attīrīto PĶR produktu atšķaida ar destilētu ūdeni līdz nepieciešamai koncentrācijai; savukārt mazākas koncentrācijas gadījumā sekvenēšanas reakcijai pievieno lielāku PĶR produkta tilpumu, attiecīgi samazinot ūdens daudzumu uz vienu reakciju.

DNS sekvenēšanas reakcijai tiek izmantots tikai viens praimeris no praimeru pāra, kas izmantots $\mathrm{PĶR} \mathrm{produkta} \mathrm{iegūšanai} \mathrm{(1.3.2.1.} \mathrm{tabula).}$ 
Sagatavo sekvenēšanas reakcijas maisījumu (sastāvs norādīts vienai reakcijai):

sekvenēšanas buferšķīidums

Big Dye v3.1.

praimeris

PĶR produkts (koncentrācija 5 ng/ul)

$\mathrm{H} 2 \mathrm{O}$
$2 \mu 1$

$0,15 \mu 1$

$1 \mu 1$

$3 \mu 1$

$3,85 \mu 1$

Sekvenēšanas reakcijas maisījumu izkliedē pa $10 \mu \mathrm{l}$ PĶR platē.

PĶR plati ievieto ciklerā un izvēlas attiecīgu programmu:

$95^{\circ} \mathrm{C}$

$94{ }^{\circ} \mathrm{C}$

$58^{\circ} \mathrm{C}$

$60{ }^{\circ} \mathrm{C}$

$72{ }^{\circ} \mathrm{C}$

$40{ }^{\circ} \mathrm{C}$
1 minūte

25 sekundes

20 sekundes

$\times 30$

30 sekundes

40 sekundes

5 minūtes 
Sekvenēšanas reakcijas produktu attīrǐšana:

Sagatavotajam produktam platē katrā bedrītē pievieno $1 \mu \mathrm{l} \mathrm{NaOAc}$ un $20 \mu 196 \%$ etanola.

Plati ievieto Eppendorf centrifūgā un centrifugē 40 minūtes $4{ }^{\circ} \mathrm{C}$ temperatūrā pie 3200 rpm apgriezieniem.

Nolej etanola / NaOAc maisījumu, plati novieto uz filtrpapīra centrifūgā otrādi un centrifugē 2-3 sekundes.

Katrā bedrītē pievieno $70 \mu 170 \%$ etanola un centrifugē 15 minūtes $4{ }^{\circ} \mathrm{C}$ temperatūrā pie 3200 rpm apgriezieniem.

Nolej etanolu un ieliek 1 minūti $95^{\circ} \mathrm{C}$ temperatūrā, lai iztvaiko liekais etanols.

Pievieno $10 \mu 1$ formamīda un aiztaisa ar plates plēvi.

PĶR plati ieliek ciklerā un izvēlas attiecīgu programmu:

$95{ }^{\circ} \mathrm{C} \quad 2$ minūtes

$40{ }^{\circ} \mathrm{C} \quad 5$ minūtes.

Sekvenēšanai tiek izmantots $36 \mathrm{~cm}$ garš kapilārs un polimērs $P O P-7$ ar Applied Biosystems ieteiktajiem standartapstākḷiem elektroforēzei.

\subsection{Datu statistiskā analīze}

Datu apstrāde tika veikta, izmantojot datorprogrammas IBM SPSS v.21. Kvantitatīvie mainīgie lielumi tika aprakstīti ar centrālās tendences rādītājiem - modu (Mo), aritmētisko vidējo (M) un standartnovirzi (SD). Gadījumos, kad datu sadalījums krasi atšksiras no normālsadalījuma, tika aprēķināta mediāna $(\mathrm{Me})$, pirmā $(\mathrm{Q} 1)$ un trešā (Q1) kvartīle un starpkvartīḷu izkliedes amplitūda $(\Delta \mathrm{Q})$.

Kvantitatīvo pazīmju statistiskā efekta novērtěšanai, pielietojot Koena „d” vērtīibu (Cohen's d), tika izmantots šāds efekta iedalījums: 
- $0,1-0,20$ (mazs)

- $0,20-0,50$ (vidējs)

$\bullet>0,50$ (liels).

Normālsadalījuma atbilstības pārbaudei tika izmantots Šapiro-Vilka (Shapiro-Wilk) tests.

Par būtiskuma līmeni $\alpha$ tika izvēlēta vērtība 0,05 ; tādējādi statistisko testu aprēķinātā p-vērtība, kas mazāka par 0,05, tiek uzskatīta par statistiski ticamu. Ja statistiskajā testā iegūtā p-vērtība būs lielāka par būtiskuma līmeni, tad nulles hipotēze netiek noraidīta. Ja testā iegūtā p-vērtība būs mazāka par būtiskuma līmeni, tad nulles hipotēze tiek noraidīta un pieņemta alternatīvā hipotēze. Statistiskā testa rezultāta pierakstā tika norādīta precīza p-vērtība un 95\% ticamības intervāla $(\mathrm{TI})$ robežas.

Kategoriskie jeb kvalitatīvie main̄̄gie lielumi tika raksturoti kā skaits un procentuālā proporcija.

Kategoriskās jeb kvalitatīvās neatkarīgās pazīmes tika salīdzinātas ar Pīrsona $\chi^{2}$ (Pearson chi square) testu vai Fišera (Fisher) eksakto testu atbilstoši to lietošanas nosacījumiem.

Kategorisko datu analīzei statistiskā efekta novērtēšanai tika izmantota Krāmera V (Cramer's V) vērtība ar šādu iedalījumu:

- $0,1-0,3$ (mazs)

• $0,3-0,5$ (vidējs)

$\bullet>0,5$ (liels).

Dzīvildzes rādītāju analīze tika veikta, izmantojot Kaplana-Meijera (Kaplan-Meier) metodi ar log-rank testu un Koksa (Cox) proporcionālo draudu regresijas (proportional hazards regression) modeli. 


\section{REZULTĀTI UN TO ANALĪZE}

\subsection{Rezultāti un to analīze ķirurğiski ārstēto un kompleksu terapiju saṇēmušo pacientu grupā}

\subsubsection{Pacientu grupas raksturojums}

Laika periodā no 2005. līdz 2011. gadam 40 pacientiem ar divām un vairāk cerebrālām metastāzēm tika veikta viena vai vairākas kraniotomijas vienas operācijas laikā. Pacientu vidējais vecums ir 58,13 gadi (standartnovirze - 10,56). Minimālais vecums ir 35 gadi, bet maksimālais - 82 gadi, vecuma amplitūda ir 47 gadi. Modālais jeb visbiežāk sastopamais vecums ir 51 gads, vidējais vecums - 56 gadi. Pirmā vecuma kvartīle ir 51 gads, trešā vecuma kvartīle - 67 gadi, vecuma starpkvartịlu izkliedes amplitūda ir 16 gadi, kas nozīmēe, ka 50\% pacientu ir vecumā no 51 līdz 67 gadiem. No pētījumā iekl̦autajiem 40 pacientiem 20 pacienti (50\%) bija sievietes un 20 pacienti $(50 \%)$ - vīrieši. Sieviešu vidējais vecums $(\mathrm{SD})$ ir $54,15(8,81)$, bet vīriešu vidējais vecums $(\mathrm{SD})$ - 62,10 $(10,87)$ gadi.

Biežākās primārā vēža histologiiskās formas bija melanoma $(\mathrm{n}=15)$ un krūts vēzis $(\mathrm{n}=9)$.

Lielākajai daļai - 23 pacientiem $(57,5 \%)$ - bija pieejami dati par kontrolētu pamatslimību, turpretī 17 pacientiem (42,5\%) tika konstatēta pamatslimības progresija.

Savukārt 24 slimniekiem (60\%) bija vērojama metahrona metastāžu attīstība, 11 gadījumos (27\%) smadzeņu metastāzes tika diagnosticētas sinhroni ar pamatslimību, bet 5 gadījumos (13\%) primārais saslimšanas avots netika diagnosticēts. 
Pirms paredzētās operatīvās ārstēšanas visiem pacientiem tika veikta neirologiskā statusa izvērtēšana un tika iegūti šādi rezultāti: 23 pacientiem (57,5\%) pirms operācijas novērota neiroloǵiskā perēkḷa simptomātika, turpretī 17 pacienti bija bez neirologiiska deficīta, taču diagnosticēt cerebrālu metastāžu klātieni ļāva paaugstināta intrakraniālā spiediena simptomātika $(\mathrm{n}=10)$, kas izpaudās kā galvassāpes, slikta dūša un vemšana. Savukārt 5 no 17 slimniekiem saslimšana izpaudās ar krampju lēkmēm (ǵeneralizētām vai parciālām), bet 2 slimniekiem cerebrālās metastāzes konstatēja, veicot plašu izmeklēšanu saistībā ar pamatslimību. 18 pacientu (45\%) klīniskais stāvoklis pirms operatīvas ārstēšanas pēc Karnofska skalas bija $\geq 70$ ballēm.

Iedalot pacientus pa $R P A$ klasēm, $R P A$ I klasei atbilda 10 pacientu dati, $R P A$ II klasei - 8 pacientu dati, bet RPA III klasei - 22 pacientu dati.

Atbilstoši magnētiskās rezonanses kontrastizmeklējuma rezultātiem 24 pacientiem cerebrālās metastāzes lokalizējās kādā no smadzeṇu pusložu rajoniem, bet 3 pacientiem metastāzes lokalizējās kādā no anatomiski dziḷas un klīniski izteikti nozīmīgas lokalizācijas vietām (bazālajos ganglijos, thalamus, smadzeņu stumbrā, corpus callosum, smadzen̄̄šs puslodēs). Savukārt 13 pacientiem metastāzes lokalizējās gan vienā, gan otrā no iepriekš minētajām lokalizācijas vietām.

Metastāžu izmēri atbilstoši magnētiskās rezonanses kontrastizmeklējumu datiem bija robežās no 1,2 līdz $4,6 \mathrm{~cm}$, vidējais izmērs $\mathrm{M}=2,44, \mathrm{SD}=0,80 \mathrm{~cm}$.

Diagnosticēto metastāžu skaits operētajiem slimniekiem: divas metastāzes - 20 gadījumos, trīs metastāzes -11 gadījumos, četras metastāzes 6 gadījumos, piecas un vairāk metastāzes -3 gadījumos. 


\subsection{2. Ķirurğiskā pieeja un metastāžu evakuācijas apjoms}

Atkarībā no cerebrālu metastāžu skaita un lokalizācijas tika pielietotas vairāku tipu ķirurğiskās pieejas: a) 32 gadījumos - viena osteoplastiska trepanācija; b) 7 gadījumos - divas osteoplastiskas trepanācijas; c) 1 gadījumā - trīs osteoplastiskas trepanācijas. Visas trepanācijas tika veiktas vienas operācijas laikā.

31 gadījumā tika pielietota operatīiva terapija pacientiem ar diagnosticētām 2-3 cerebrālām metastāzēm, bet 9 gadījumos - pacientiem ar 4-6 cerebrālām metastāzēm.

17 pacientiem tika evakuētas visas diagnosticētās cerebrālās metastāzes. 12 gadījumos tie bija pacienti ar divām metastāzēm, bet 5 gadījumos ķirurğiski tika evakuētas visas trīs no diagnosticētajām trim cerebrālajām metastāzēm. 23 pacientiem metastāzes tika evakuētas daḷēji, t. i., evakuēja tās, kuras bija novietotas simptomātiskās un ķirurgíski pieejamās lokalizācijas vietās. 8 gadījumos tie bija pacienti ar divām cerebrālām metastāzēm, 6 gadījumos pacienti ar trim metastāzēm, 5 gadījumos - pacienti ar četrām cerebrālām metastāzēm un 4 gadījumos - pacienti ar piecām un sešām cerebrālām metastāzēm.

Radikāla metastāžu evakuācija bija iespējama pacientiem ar divām un trim cerebrālām metastāzēm. Pacientiem ar divām metastāzēm viena metastāze tika evakuēta 8 gadījumos (40\%), bet visas metastāzes - 12 gadījumos (60\%); savukārt trīs metastāžu gadījumā viena metastāze evakuēta 2 gadījumos (18\%), divas metastāzes - 4 (36\%) un visas - 5 gadījumos (46\%). Turpretī pacientiem ar četrām līdz sešām metastāzēm evakuācijas apjoms bija tikai daļējs. 


\subsubsection{Perioperatīvas komplikācijas}

Perioperatīvās komplikācijas tika reǵistrētas 30 dienu laikā pēc operatīvas terapijas un tika iedalītas divās turpmāk minētajās grupās:

1) lokālas komplikācijas, kas saistītas ar ķirurğiskās pieejas vietu;

2) sistēmiskas komplikācijas, kas saistītas ar ekstrakraniālām metastāzēm un blakusslimību dekompensāciju.

Pēcoperāciju periodā tika novērotas trīs lokālas komplikācijas (viens postoperatīvs meningīts sakarā ar brūces likvoreju un divas lokālas hemorāgijas operācijas ložā), kam nebija nepieciešama brūces revīzija un hematomas evakuācija.

30 dienu pēcoperācijas mirstība novērota 4 gadījumos (perioperatīva mortalitāte 10\%). Nāves iemesls dotajos gadījumos bija strauja ekstrakraniālā audzēja progresija (3 gadījumi, pacienti ar preoperatīvu $K P S<70$ ballēm atbilda $R P A$ III klasei) un akūta kardiopulmonāla mazspēja (1 gadījums).

\subsubsection{Pēcoperācijas pacientu klīniskā stāvokḷa izvērtējums pēc Karnofska skalas}

Pēc operācijas, pacientiem izrakstoties no stacionāra, tika veikta atkārtota slimnieku klīniskā stāvokḷa izvērtēšana pēc Karnofska skalas. Izvērtējums 37,5\% gadījumu (15 pacientiem) norādīja uz pacienta agrīnā klīniski funkcionālā stāvokḷa uzlabošanos par 10 ballēm pēc Karnofska skalas. 60\% gadījumu (24 pacientiem) klīniskais stāvoklis nemainījās un tika novērtēts kā stabils, bet vienā gadījumā pasliktinājās par 10 ballēm.

Veicot KPS rādītāju salīdzinājumu postoperatīvā periodā pacientu grupām ar 2-3 vai 4-6 cerebrālām metastāzēm, tika noskaidrots, ka labāki rādītāji (stabils klīniskais stāvoklis vai KPS rādītāja uzlabojums) bija vērojami pacientu grupai ar 2-3 cerebrālām metastāzēm. 


\subsubsection{Postoperatīvās dzīvildzes rādītāji un to ietekmējošo faktoru analīze}

Pacientu pēcoperācijas dzīvildzes rādītāji tika analizēti, izmantojot Kaplana-Meijera metodi, atbilstoši kurai tika aprēķināts, ka mediānā dzīvildze visai ķirurğiski ārstēto un kompleksu terapiju saṇēmušo pacientu grupai bija 4,86 mēneši (95\% TI: 3,24-6,47). Kaplana-Meijera dzīvildzes līkne 40 pacientu grupai attēlota 2.1.5.1. attēlā.

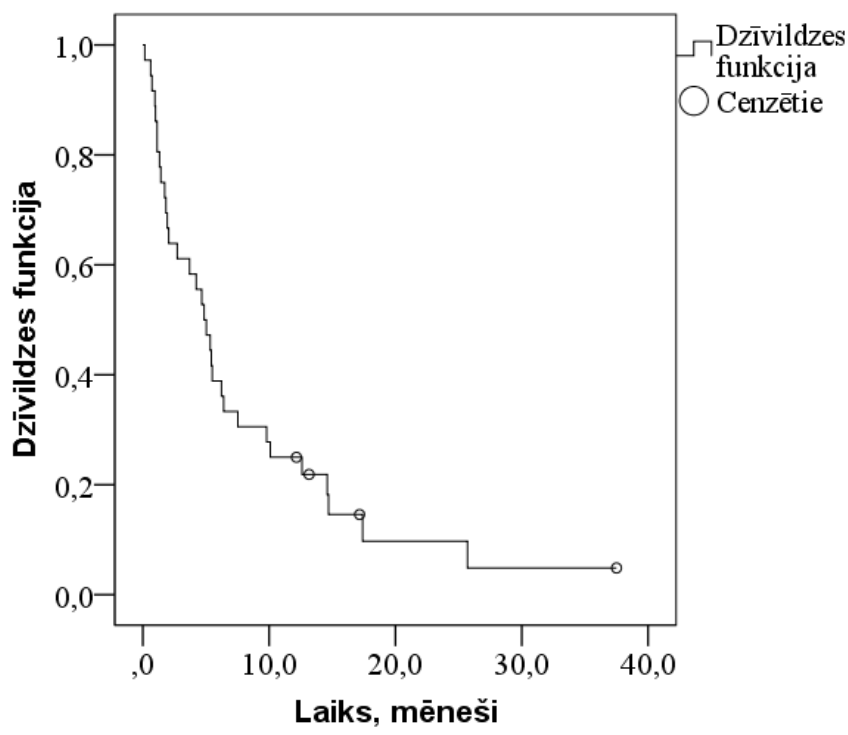

2.1.5.1. attēls. 40 pacientu grupas postoperatīvās dzīvildzes līkne

No to 40 pacientu grupas, kuri tika ārstēti, veicot totālu vai dal̦ēju ķirurǵisku metastāžu evakuāciju un kompleksu terapiju, pēcoperācijas dz̄̄vildzes rādītāji 30 pacientiem (75\%) nesasniedza vienu gadu, turpretī 8 pacientiem (20\%) pēcoperācijas dzīvildze pārsniedza 1 gadu, bet nepārsniedza 
2 gadus. Vairāk nekā divu gadu pēcoperācijas dzīvildzi sasniedza 2 pacienti (5\%), skat. 2.1.5.2. attēlu.

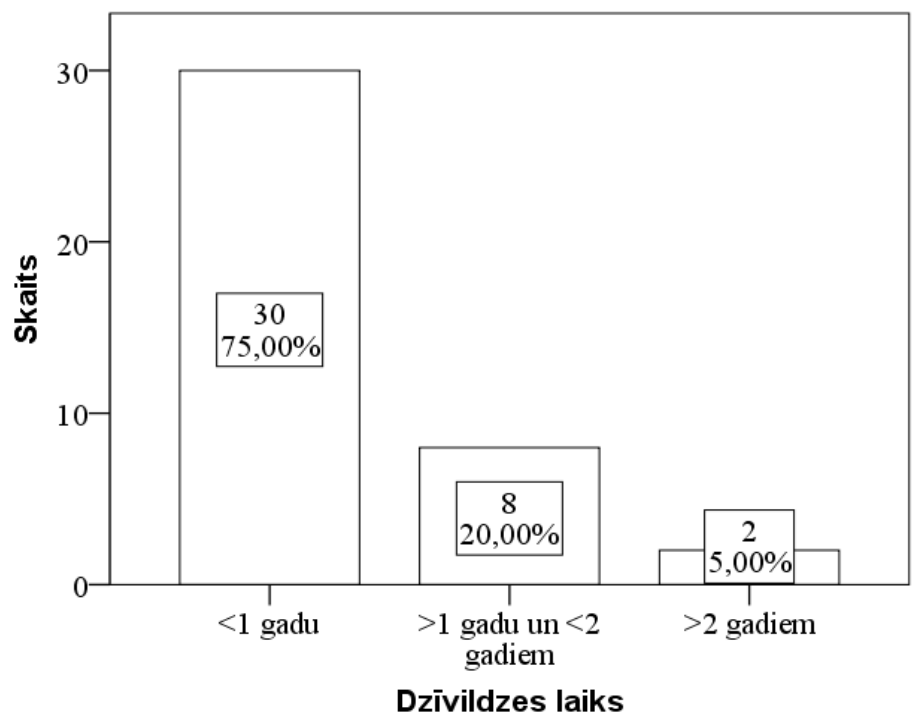

\subsubsection{2. attēls. 1 un 2 gadu postoperatīvās dzīvildzes rādītāji}

N̦emot vērā pēcoperācijas dzīvildzes rezultātu datus par to, ka visvairāk pacientiem (75\%) nāve iestājas pirmā gada laikā, papildus šajā laika periodā tika veikta dzīvildzes datu sadalījuma analīze. Mediānā dzīvildze pirmā gada laikā ir 3,16 mēneši, bet visbiežāk sastopamā jeb modālā mirstība ir 1,1 mēnesis un sadalījuma asimetrijas rādītājs (SK) - 0,76 (0,42). Pirmajā pēcoperācijas gadā 1,3 līdz 5,5 mēnešu laika intervālā nāve iestājās 50 procentiem pacientu no šīs pacientu grupas.

Izvērtējot pēcoperācijas dzìvildzes rādītājus attiecībā uz evakuēto cerebrālo metastāžu histoloǵiskās analīzes rezultātiem, vissliktākā prognoze bija olnīcu un dzemdes kakla vēža gadījumā (3,41 mēnesis), turpretī visgarākā 
dzīvildze tika novērota nieru vēža pacienta gadījumā (14,7 mēneši). Taču iegūtie dati nel̦āva veikt statistisko analīzi, ņemot vērā mazo pacientu skaitu attiecīgajās grupās. Visbiežāk sastopamajām primārā vēža formām vidējās dzīvildzes rādītāji praktiski neatšķīrās, - attiecīgi 7,8 mēneši melanomas gadījumā un 7,9 mēneši krūts vēža gadījumā.

\subsubsection{Pēcoperācijas dz̄ivildzi ietekmējošo faktoru vienvariantu analīze}

Tika veikta vienvariantu analīze ar Manna-Vitnija U (Mann-Whitney $U$ ) testa palīdzību šādiem postoperatīvas dzīvildzes ilgumu ietekmējošiem faktoriem (skat. 2.1.5.1.1. tabulu):

2.1.5.1.1. tabula.

40 pacientu grupu raksturojošie rādītāji un dzīvildze (mēnešos)

\begin{tabular}{|c|c|c|c|}
\hline Pazīme & $\mathbf{N}$ & Mediānā dzīvildze (95\% TI), mēneši & p-vērtīiba \\
\hline $\begin{array}{l}\text { Dzimums } \\
\text { Vīrieši } \\
\text { Sievietes }\end{array}$ & $\begin{array}{l}20 \\
20\end{array}$ & $\begin{array}{l}5,33(4,45-6,20) \\
2,06(0,30-3,81)\end{array}$ & 0,59 \\
\hline $\begin{array}{l}\text { Vecums (gados) } \\
\geq 65 \\
<65\end{array}$ & $\begin{array}{l}30 \\
10\end{array}$ & $\begin{array}{l}5,33(4,20-6,45) \\
3,70(0,13-7,26)\end{array}$ & 0,12 \\
\hline $\begin{array}{l}\text { Prezentācija } \\
\text { Sinhroni } \\
\text { Metahroni }\end{array}$ & $\begin{array}{l}29 \\
11 \\
\end{array}$ & $\begin{array}{l}7,53(2,61-23,45) \\
3,70(1,06-6,33) \\
\end{array}$ & 0,46 \\
\hline $\begin{array}{l}\text { Primārā audzēja kontrole } \\
\mathrm{Jā} \\
\mathrm{Ne}\end{array}$ & $\begin{array}{l}23 \\
17\end{array}$ & $\begin{array}{l}3,60(0,83-6,37) \\
5,50(3,65-7,34)\end{array}$ & 0,90 \\
\hline $\begin{array}{l}\text { Metastāžu skaits } \\
2-3 \\
4-6\end{array}$ & $\begin{array}{l}29 \\
11\end{array}$ & $\begin{array}{l}5,5(3,09-7,90) \\
2,06(0,1-4,72)\end{array}$ & $0,03 *$ \\
\hline $\begin{array}{l}\text { Preoperatīva } K P S \\
\geq 70 \\
<70\end{array}$ & $\begin{array}{l}18 \\
22\end{array}$ & $\begin{array}{l}5,43(2,58-8,27) \\
2,06(0,1-5,73)\end{array}$ & $0,02 *$ \\
\hline $\begin{array}{l}\text { RPA } \\
\text { I } \\
\text { II } \\
\text { III }\end{array}$ & $\begin{array}{l}10 \\
8 \\
22\end{array}$ & $\begin{array}{l}12,07(2,16-21,97) \\
4,86(3,20-6,52) \\
2,06(0,1-5,73)\end{array}$ & $<0,05^{*}$ \\
\hline
\end{tabular}


2.1.5.1.1. tabulas turpinājums

\begin{tabular}{|l|l|l|l|}
\hline Rezekcijas radikalitāte & 17 & $6,23(3,40-9,05)$ & $<0,01^{*}$ \\
Visi & 23 & $2,06(0,1-5,14)$ & \\
Parcīāli & & & \\
\hline Postoperatīva $W B R T$ & 11 & $4,66(0,1-10,90)$ & 0,41 \\
Jā & 29 & $4,86(2,70-7,02)$ & \\
Nē & & $4,66(0,1-11,08)$ & \\
\hline Postoperatīva k̦īmijterapija & 7 & $5,03(3,02-7,03)$ & 0,58 \\
Jā & 33 & $5 \bar{N}$ & \\
Nē &
\end{tabular}

Statistiski ticama $(\mathrm{p}<0,05)$ ietekme dzīvildzes analīzē tika konstatēta šādiem faktoriem: 1) rezekcijas radikalitātei; 2) metastāžu skaitam; 3) RPA klasei; 4) KPS pirmsoperācijas rādītājam.

Pacientu grupai, kurai tika veikta radikāla visu diagnosticēto cerebrālo metastāžu evakuācija, dz̄ivildze bija būtiski garāka, nekā pacientu grupai, kurā tika ietverti pacienti, kam parciāli evakuēja cerebrālās metastāzes, $\mathrm{p}<0,01$. Visu cerebrālo metastāžu evakuācijas gadījumā pacientu mediānā dzīvildze bija 6,23 mēneši (95\% TI: 3,40-9,05), turpretī cerebrālu metastāžu parciālas evakuācijas gadījumā mediānā dz̄ivildze bija 2,06 mēneši (95\% TI: 0,1-5,14). Pamatojoties uz log-rank testu, tika secināts, ka rezekcijas radikalitāte statistiski ticami ietekmē pacientu dzīvildzi $(\mathrm{p}<0,05)$ un, kā vizuāli redzams no 2.1.5.1.1. attēla, visu metastāžu rezekcija pagarina dzīvildzi. 


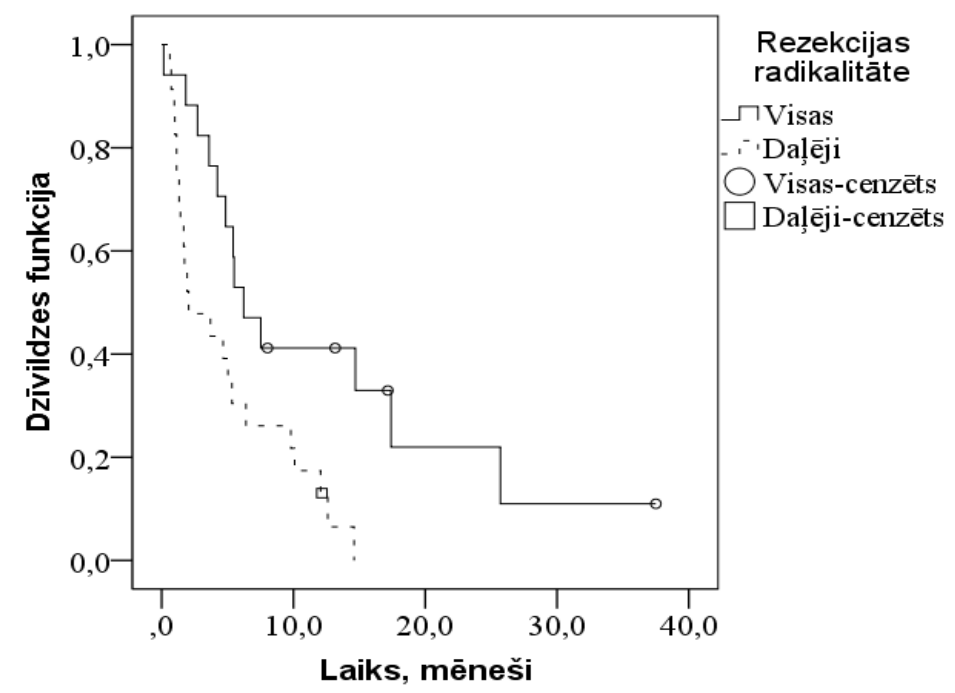

\subsubsection{1. attēls. Kaplana-Meijera dzīvildzes līknes atkarībā no rezekcijas apjoma (viss/parciāli)}

Analizējot metastāžu skaitu, 2-3 cerebrālu metastāžu gadījumā pacientu mediānā pēcoperācijas dzīvildze bija 6,23 mēneši (95 \% TI: 3,10-7,10), turpretī 4-6 cerebrālu metastāžu gadījumā mediānā dzīvildze bija 2,06 mēneši (95\% TI: 0,1-4,72). Metastāžu skaitam bija ne tikai vizuāli novērojama (2.1.5.1.2. attēls), bet arī statistiski ticama (log-rank tests, $\mathrm{p}=0,03)$ ietekme uz dzīvildzi, un pacientu grupai ar 2-3 cerebrālām metastāzēm dzīvildze bija statistiski ticami garāka, nekā pacientu grupai ar 4-6 cerebrālām metastāzēm. 


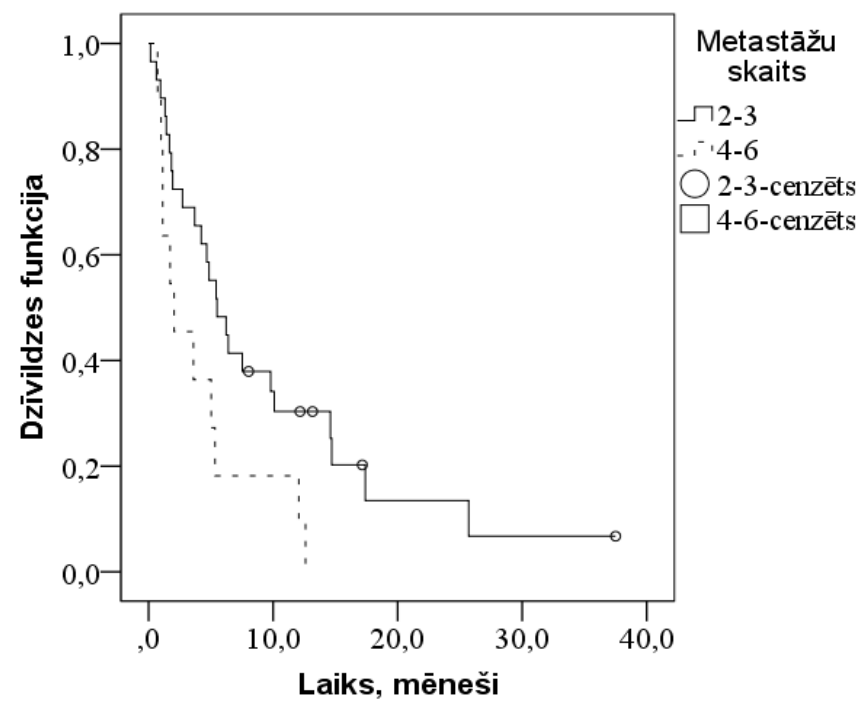

\subsubsection{2. attēls. Kaplana-Meijera dzīvildzes līknes atkarībā no metastāžu skaita (2-3/4-6)}

Pacientus iedalot RPA I, II un III klasēs, pēcoperācijas dzīvildzes rādītāji bija attiecīgi 12,07 mēneši (95\% TI: 2,16-21,97), 4,86 mēneši (95\% TI: 3,20-6,52) un 2,06 mēneši (95\% TI: 2,06-5,73). Pamatojoties uz log-rank testu, secināts, ka pacienta piederība $R P A$ klasei statistiski ticami $(\mathrm{p}<0,05)$ ietekmē pacientu dzīvildzi un, kā vizuāli redzams no 2.1.5.1.3. attēla, pieaugot $R P A$ klasei, dzīvildze attiecīgi saīsinās. 


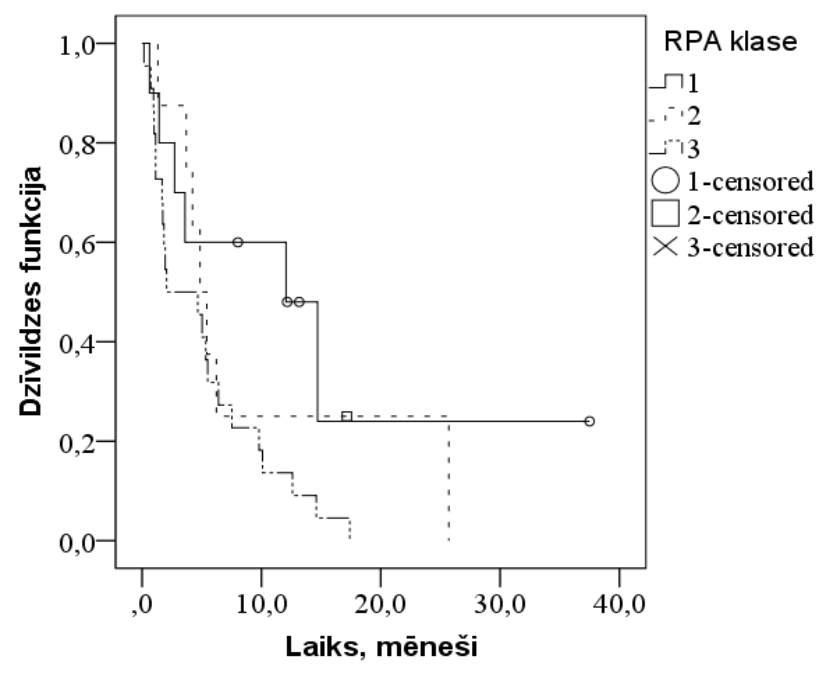

\subsubsection{3. attēls. Kaplana-Meijera dzīvildzes līknes atbilstoši RPA I, II un III klasēm}

Analizējot pirmsoperācijas KPS rādītājus, iegūti turpmāk minētie dati, ka pacientu grupai ar KPS rādītāju $\geq 70$ ballēm dzìvildze bija statistiski ticami (log-rank tests, $\mathrm{p}<0,01$ ) atšķirīga no to pacientu grupas, kurā tika ietverti pacienti ar KPS rādītāju $<70$ ballēm. Pacientu, kuru KPS bija $\geq 70$ ballēm, mediānā dzīvildze bija 5,43 mēneši (95\% TI: 2,58-8,27), turpretī tiem pacientiem, kuru KPS rādītājs bija $<70$ ballēm, mediānā dzīvildze bija 2,06 mēneši (95\% TI: 0,1-5,73). Pacientu grupu Kaplana-Meijera dzīvildzes līkne atbilstoši $K P S \geq 70 / K P S<70$ rādītājam attēlota 2.1.5.1.4. attēlā. 


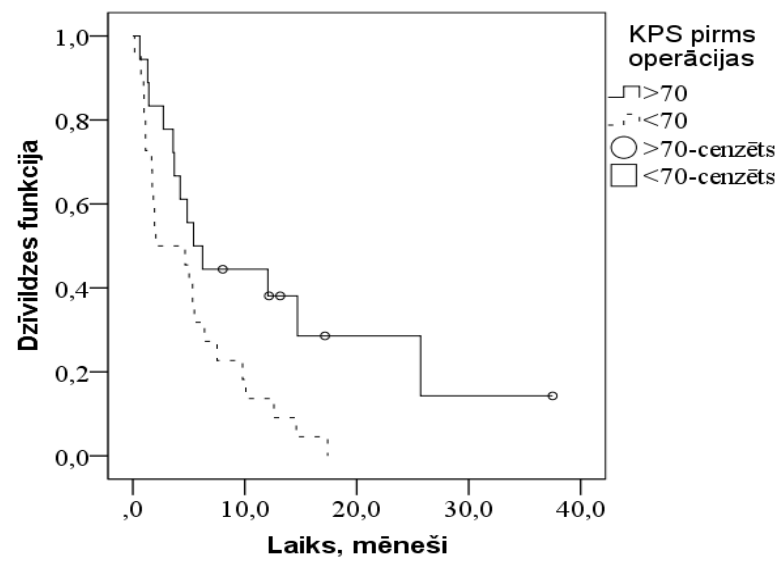

2.1.5.1.4. attēls. Kaplana-Meijera dzīvildzes līknes atbilstoši KPS rādītājam $(\geq 70 /<70)$

\subsubsection{Pēcoperācijas dzīvildzi ietekmējošo faktoru daudzvariantu analīze}

Tie prognostiskie faktori, kas uzrādīja statistiski ticamu $(\mathrm{p}<0,05)$ ietekmi vienfaktora analīzē (rezekcijas radikalitāte, metastāžu skaits, RPA klase, KPS pirmsoperācijas rādītājs), tika iekḷauti multivariatīvajā analīzē, izmantojot Koksa proporcionālo risku modeli. Rezultāti apkopoti 2.1.5.2.1. tabulā. N̦emot vērā pētījumā iekḷauto pacientu skaitu, neviena no pazīmēm, kas bija statistiski ticama vienvariantu analīzē, Koksa proporcionālo draudu regresijā nav statistiski ticama, tomēr, kā redzams no 3.1.5.2.1. tabulas, draudu attiecība $(H R)$ grupai, kuras $K P S \geq 70$, ir 2,05 reizes lielāka, nekā KPS < 70 grupai. Līdzīgi, analizējot metastāžu skaita grupu, varam secināt, ka 4-6 metastāžu grupai draudu attiecība $(H R)$ ir 1,58 salīdzinājumā ar 2-3 metastāžu grupu. Mazliet augstāka draudu attiecība $(H R=1,95)$ ir visu metastāžu rezekcijas gadījumā salīdzinoši ar pacientu grupu, kurai metastāzes tika rezecētas daliēji. 


\section{Daudzvariantu analīzes rezultāti}

\begin{tabular}{|l|l|l|}
\hline Rādītājs & p-vērtība & HR $(\mathbf{9 5} \%$ TI $)$ \\
\hline Preoperatīva $K P S(\geq 70 /<70)$ & 0,14 & $2,05(0,77-5,45)$ \\
\hline$R P A$ klase (I, II, III) & 0,23 & $1,98(0,63-6,22)$ \\
\hline Metastāžu skaits (2-3 / 4-6) & 0,27 & $1,58(0,69-3,65)$ \\
\hline $\begin{array}{l}\text { Rezekcijas apjoms (visu metastāžu rezekcija / } \\
\text { parciāla rezekcija) }\end{array}$ & 0,17 & $1,95(0,74-5,15)$ \\
\hline
\end{tabular}

\subsection{6. Ķirurǵiski ārstēto un kompleksu terapiju saṇēmušo pacientu grupu 1., 2., 3. un 4. protokola ārstēšanas gaita un rezultāti}

No 40 pacientiem 17 (42,5\%) bija iespējams veikt visu cerebrālo metastāžu ķirurǵisku evakuāciju un, ņemot vērā operatīvās terapijas radikalitāti, tālāka kompleksa terapija netika pielietota.

No 23 pacientiem $14(60,86 \%)$ pēc parciālas cerebrālo metastāžu kirurğiskas evakuācijas agrīnā pēcoperācijas periodā tika pielietota kompleksa terapija - vai nu visu galvas smadzeņu apstarošana (WBRT), ko saņēma 9 pacienti, vai arī visu galvas smadzeņu apstarošana (WBRT) kopā ar ķīmijterapiju $(\mathrm{CH})-5$ pacientiem.

No 23 pacientiem, kuriem netika evakuētas visas cerebrālās metastāzes, 9 pacientiem $(39,13 \%)$ tālāka kompleksa terapija netika pielietota.

Pēcoperācijas mediānās dzīvildzes rādītāji atbilstoši pielietotajam ārstēšanas protokolam apkopoti 2.1.6.1. tabulā. 
2.1.6.1. tabula

Pēcoperācijas mediānās dzīvildzes rādītāji dažādu ārstēšanas protokolu pacientiem

\begin{tabular}{|c|c|c|}
\hline Protokola Nr. & Pacientu skaits & $\begin{array}{l}\text { Mediānā dz̄ìildze } \\
\text { (95\% TI, mēneši) }\end{array}$ \\
\hline 1. Ķirurgija (viss) & 17 & $6,23(3,40-9,05)$ \\
\hline 2. Ķiruǵija (dalēeji) & 9 & $1,73(0,85-2,60)$ \\
\hline 3. Ķirugíija (daḷēji) +WBRT & 9 & $5,33(0,1-15,26)$ \\
\hline $\begin{array}{l}\text { 4. Ķiruǵija } \\
\text { (dal̦ēji)+WBRT+CH }\end{array}$ & 5 & $4,86(3,15-6,56)$ \\
\hline
\end{tabular}

Analizējot pēcoperācijas dzīvildzes rezultātus atkarībā no pielietotā ārstēšanas protokola, tika iegūts, ka izvēlētajam ārstēšanas protokolam ir statistiski ticama ietekme uz dzīvildzi atbilstoši Kaplana-Meijera metodei (log-rank tests, $\mathrm{p}=0,01)$.

Kā redzams no 2.1.6.1. tabulas, visgarākā dzīvildze (6,23 mēneši $(95 \%$ TI: 3,40-9,05)) ir tiem pacientiem, kuriem veikta visu metastāžu rezekcija, savukārt vis̄̄sākā dzīvildze (1,73 mēneši $(95 \%$ TI: 0,85-2,60)) ir pacientiem, kuriem veikta daļēja metastāžu rezekcija Veicot daḷeju metastāžu evakuāciju un tālākā ārstēšanas gaitā pielietojot kombinēto staru terapiju vai staru un ķ̄imijterapiju, vidējās dzīvildzes rādītāji bija aptuveni līdzīgi. 


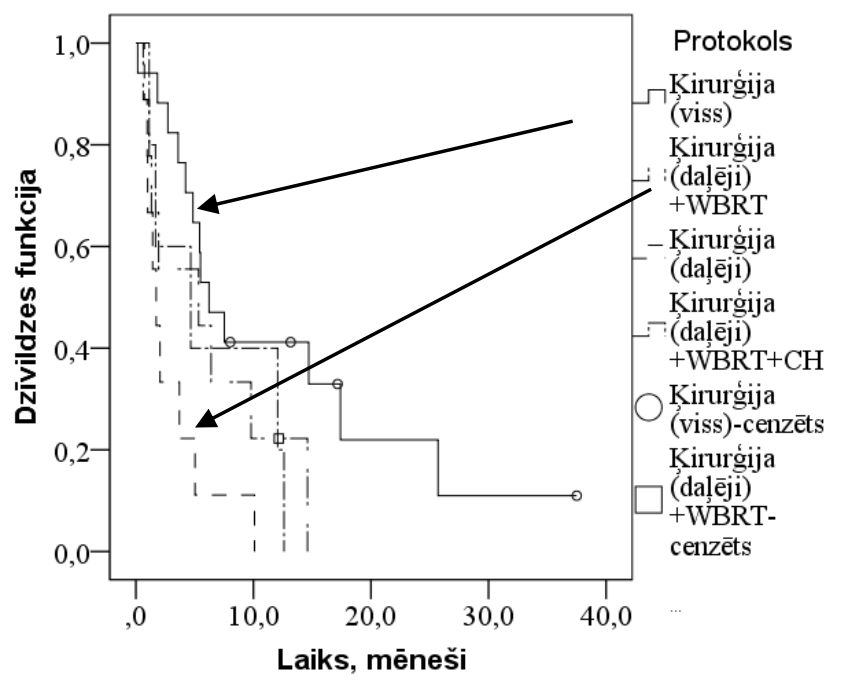

\subsubsection{1. attēls. Kaplana-Meijera dzīvildzes līknes atbilstoši pielietotajam ārstēšanas protokolam}

\subsection{Rezultāti radioķirurğiski ārstēto pacientu grupā}

Radioķirurgíiskās terapijas novitāte Latvijā bija par pamatu faktam, ka pētījumā tika iekḷauti ne tikai pacienti ar divām un vairāk galvas smadzeņu metastāzēm, bet arī vienas smadzeņu metastāzes slimnieki ar mērḳi izanalizēt Latvijā pilnīgi jaunas metodes pielietojuma rezultātus.

Jāuzsver, ka arī vienas metastāzes radioķirurǵiskas ārstēšanas rezultāti ir loti būtiski pacientiem ar divām un vairāk metastāzēm, jo, izvēloties pielietot radioķirurgiisku ārstēšanu, svarīgāks par metastāžu skaitu ir ārstētās mērķa patologijas kopējais tilpums (piemēram, līdzvērtīgi tilpuma rādītāji var būt divām mazām un vienai lielai metastāzei), un gadījumos, kad pacientam ar divām vai vairāk metastāzēm ķirurğiski neizdodas evakuēt visus mezglus, tālākai radioķirurğiskai terapijai var pakḷaut vienu vai vairākas no atlikušajām cerebrālajām metastāzēm. 
Divu gadu laika periodā (2010.-2011.) 16 pacientiem ar vienu vai vairākām cerebrālām metastāzēm tika pielietota radioḳirurg̣iska vai frakcionēta radioķirurğiska ārstēšana. Pacientu vidējais vecums $-\mathrm{M}=59,88(\mathrm{SD}=8,77)$, minimālais vecums - 45 gadi, bet maksimālais - 75 gadi, vecuma amplitūda 30 gadi, vidējais vecums - 61 gads. Pacientu vecuma histogramma attēlota 3.2.1. attēlā. No šiem pacientiem 11 bija sievietes $(\mathrm{M}=59,72 ; \mathrm{SD}=8,37)$ un 5 vīrieši $(M=60,20 ; S D=10,63)$. Neatkarīgo izlašu t tests norādīja, ka sieviešu un vīriešu vidējais vecums statistiski ticami neatšķiras $(\mathrm{p}=0,1)$.

8 pacienti pirms stereotaktiskas radioķirurğiskas (SRS) ārstēšanas veikšanas bija saṇēmuši visu galvas smadzeņu apstarošanu (WBRT) ar kopējo devu 30 Gy (3 Gy 10 frakciju veidā).

Ar SRS ārstēto pacientu grupā lielākā pacientu daļa $(\mathrm{n}=8)$ bija pacientes ar krūts dziedzera vēža metastāzēm galvas smadzenēs. Trīs bija plaušu sīkšūnu vēža metastāžu slimnieki, divi - melanomas metastāžu, divi - olnīcu un dzemdes kakla vēža metastāžu pacienti un viena paciente ar ne-Hodžkina limfomas metastāzēm galvas smadzenēs.

2.2.1. tabula

Pacientu sadalījums pēc primārā vēža lokalizācijas

\begin{tabular}{|l|l|}
\hline \multicolumn{1}{|c|}{ Primārais audzējs } & \multicolumn{1}{c|}{ Pacientu skaits } \\
\hline Krūts vēzis & 8 \\
\hline Melanoma & 2 \\
\hline Plaušu vēzis (sīkšūnu, adenokarcinoma) & 3 \\
\hline Oln̄̄cu vai dzemdes kakla vēzis & 2 \\
\hline Ne-Hodžkina limfoma & 1 \\
\hline
\end{tabular}

Pacientiem tika veikta radioķirurgíska ārstēšana, ja to klīniskais stāvoklis pēc Karnofska skalas bija $\geq 70$.

Trim pacientiem pirms radioķirurǵiskas ārstēšanas operācijas tika novērota neirolog̣iska perēkḷa simptomātika. 11 pacienti bija bez neirologiiska deficīta preoperatīvajā periodā, bet diagnosticēt cerebrālu metastāžu klātieni l̦āva paaugstināta intrakraniālā spiediena simptomātika, kas izpaudās kāa 
galvassāpes, slikta dūša un vemšana. Diviem slimniekiem saslimšana izpaudās ar krampju lēkmēm (ǵeneralizētām vai parciālām).

11 pacientiem pēc magnētiskās rezonanses kontrastizmeklējuma rezultātiem cerebrālās metastāzes lokalizējās kādā no smadzeṇu pusložu rajoniem, trim pacientiem metastāzes lokalizējās kādā no anatomiski dziļas un klīniski izteikti nozīmīgas lokalizācijas vietām (bazālajos ganglijos, thalamus, smadzeņu stumbrā, corpus callosum, smadzenīšu puslodēs). Diviem pacientiem metastāzes lokalizējās gan vienā, gan otrā no iepriekš minētajām lokalizācijas vietām.

12 pacientiem no 16 bija vērojama metahrona metastāžu attīstība, 4 gadījumos smadzeņu metastāzes tika diagnosticētas sinhroni ar pamatslimību.

Nevienam no 16 ar SRS ārstētiem pacientiem, uzsākot terapiju, metastāzes citās orgānu sistēmās netika konstatētas.

Diagnosticēto metastāžu skaits radioḳirurgisisku ārstēšanu saṇēmušajiem slimniekiem: viena metastāze - 11 gadījumos, divas metastāzes -3 gadījumos, piecas metastāzes - 1 gadījumā, sešas metastāzes - 1 gadījumā, skat. 3.2.3. attēlu.

12 pacienti no 16 radioķirurǵisku ārstēšanu saṇēma vienas staru frakcijas veidā, turpretī 4 gadījumos tika lietota frakcionēta radioterapija 3-5 frakciju veidā. Visos gadījumos maksimālais mērķa (metastāzes) diametrs, kas tika noteikts pēc magnētiskās rezonanses T1 kontrastizmeklējuma datiem, bija mazāks par četriem centimetriem. Septiṇi pacienti $(43,75 \%)$ pirms stereotaktiskās radioķirurğijas veikšanas bija jau saņēmuši visu galvas smadzeņu apstarošanu (WBRT) ar kopējo devu 30 Gy (3 Gy 10 frakciju veidā), un saṇēma ārstēšanu vai nu jau esošo metastāžu progresijas dēḷ vai arī sakarā ar jaunām metastāzēm, kas bija izveidojušās. Pārējie astoņi pacienti pētījuma veikšanas periodā nesaņēma visu galvas smadzeņu apstarošanu (WBRT). Summārais paredzamā mērķa ārstēšanas tilpums katram pacientam bija skaitlis, 
ko veidoja saskaitītas katras atsevišķas staru terapiju saṇēmušās metastāzes tilpumu summa. Vidējais visas pacientu grupas ārstēšanas tilpums bija $16,63 \mathrm{~cm}^{3}\left(1,85-47,03 \mathrm{~cm}^{3}\right.$ robežās).

2.2.2. tabula

Pielietotās radioķirurğiskās ārstēšanas veids

\begin{tabular}{|l|l|l|l|}
\hline Ārstēšanas veids & $\begin{array}{c}\text { Pacientu } \\
\text { skaits }\end{array}$ & $\begin{array}{c}\text { Mērķa tilpums (robežas), } \\
\mathbf{c m}^{\mathbf{3}}\end{array}$ & $\begin{array}{c}\text { Marginālā deva (robežas), } \\
\mathbf{G y}\end{array}$ \\
\hline$S R S$ & 9 & $25,12(2,03-47,03)$ & $18(15-24)$ \\
\hline$W B R T+S R S$ & 3 & $8,15(1,85-15,79)$ & $18(18-20)$ \\
\hline$W B R T+F S R T$ & 4 & $22,36(6,80-39,47)$ & $15-35(3-5)$ frakcijās \\
\hline
\end{tabular}

N̦emot vērā, ka visas 16 pacientu grupas mediāno dzīvildzi nebija iespējams aprēķināt, tika aprēķināta vidējā dzīvildze, kas bija 16,02 mēneši (95\% TI: 10,73-21,32 mēneši).

Dzīvildzes dati norādīti atkarībā no turpmāk minētās pielietotās staru terapijas veida:

1) $S R S$ vai $F S R T$ kombinējot kopā ar WBRT (7 pacientiem), - vidējā dzīvildze bija 18,04 mēneši (95\% TI: 10,19-25,89);

2) $\operatorname{SRS~(9~pacientiem)~-~vidējā~dzīvildze~bija~10,75~mēneši~}$ (95\% TI: 6,25-15,25).

Pieciem pacientiem pēc radioķirurğiskas ārstēšanas magnētiskās rezonanses izmeklējumos tika konstatētas jaunas metastāzes.

Apkopojot MR izmeklējuma datus visiem pacientiem 2 mēnešus pēc radioķirurğiskas ārstēšanas (3.2.3. tabula), visas trīs metastāzes (11,11\%), kurās pēc radioķirurǵiskas ārstēšanas MR izmeklējumos tika novērota veidojuma rezorbcija (VR), bija krūts vēža ǵenēzes. Daļēja rezorbcija (DR) tika novērota astoņos gadījumos $(29,62 \%)$, un tā tika novērota piecos krūts vēža metastāžu gadījumos un pa vienam olnīcu, plaušu un ne-Hodžkina limfomas metastāzes gadījumam. Kontrolēta saslimšana (KS) bija novērota 13 gadījumos $(48,14 \%)$ 
ar piecām krūts vēža metastāzēm, piecām plaušu vēža metastāzēm, vienu melanomas metastāzi, vienu olnīcu vēža metastāzi un vienu dzemdes kakla vēža metastāzi. Metastāzes progresija (MP) tika novērota trīs gadījumos $(11,11 \%)$ - diviem melanomas un vienam plaušu vēža metastāžu slimniekam.

2.2.3. tabula

MR galvas smadzeņu metastāžu izvērtējuma rezultāti 2 mēnešus pēc veiktās radioķirurğiskās ārstēšanas

\begin{tabular}{|l|l|l|l|l|}
\hline & $\begin{array}{c}\text { Veidojuma } \\
\text { rezorbcija } \\
\text { (VR) }\end{array}$ & $\begin{array}{c}\text { Daḹja } \\
\text { rezorbcija } \\
\text { (DR) }\end{array}$ & $\begin{array}{c}\text { Kontrolēta } \\
\text { saslimšana } \\
\text { (KS) }\end{array}$ & $\begin{array}{c}\text { Metastāzes } \\
\text { progresija } \\
\text { (MP) }\end{array}$ \\
\hline Krūts vēzis & 3 & 5 & 5 & - \\
\hline Melanoma & - & - & 1 & 2 \\
\hline Plaušu vēzis & - & 1 & 5 & 1 \\
\hline $\begin{array}{l}\text { Olnīcu un } \\
\text { dzemdes kakla } \\
\text { vēzis }\end{array}$ & - & 1 & 2 & - \\
\hline $\begin{array}{l}\text { Ne-Hodžkina } \\
\text { limfoma }\end{array}$ & - & 1 & - & - \\
\hline
\end{tabular}

Datu apstrādes brīdī 9 pacienti no 16 pacientiem, kuri bija saņēmuši radioķirurğisku ārstēšanu, bija dzīvi, bet 7 - miruši.

Veicot kontroles MR izmeklējumu vienam pacientam, kurš bija saṇēmis radioķirurǵisku ārstēšanu melanomas metastāzes gadījumā, tika izteiktas aizdomas par iespējamu veiktās terapijas komplikāciju - radionekrozi metastāzes ložā (līdz šim SPECT vai PET izmeklējumi, ar kuriem varētu veikt precīzu diagnostiku, Latvijā nav pieejami). Diagnoze tika histoloǵiski apstiprināta postoperatīvi. Lēmums par operatīvu terapiju tika pieņemts, pamatojoties uz veidojuma progresiju ar sekundāru masas efektu un vispārēju neirologisku simptomu attīstību. 


\subsection{Cerebrālo metastāžu TP53 gēna analīzes rezultāti}

Tika analizēts 40 to pacientu histologisko preparātu TP53 genētiskais materiāls, kuriem ķirurğiski ārstētas divas un vairāk cerebrālas metastāzes. Klīniski nozīmīgas TP53 gēna mutācijas cerebrālo metastāžu histoloǵiskajos preparātos tika konstatētas 11 pacientiem (27,5\%) (skatīt 2.3.1. tabulu).

Visbiežāk (3 histologisko preparātu materiālos no 9) TP53 gēna mutācijas tika konstatētas krūts vēža pacientēm.

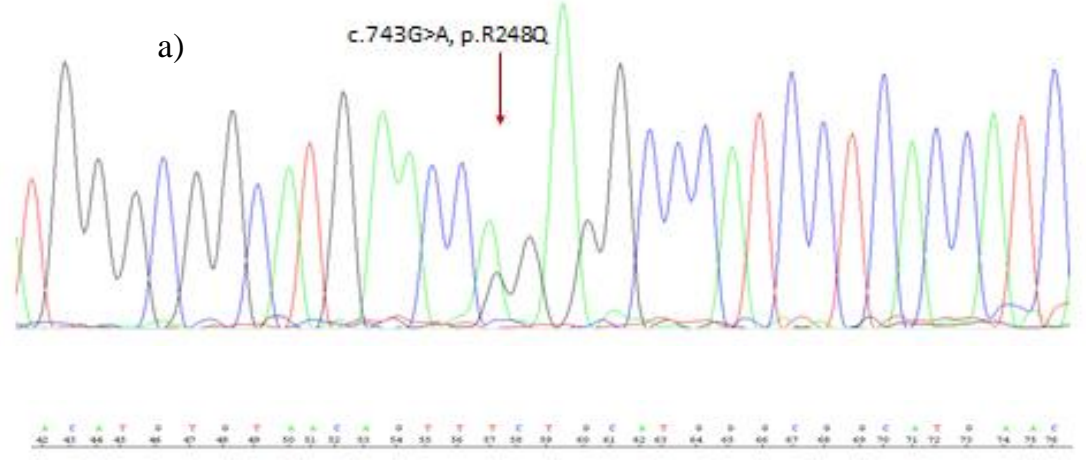

b)

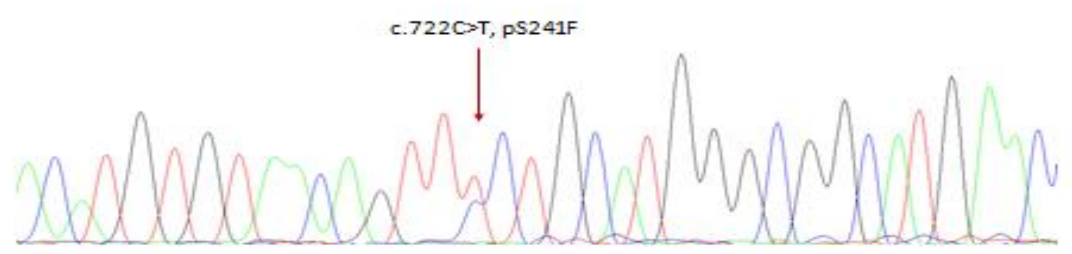

2.3.1. attēls. Piemērs ar TP53 gēna klīniski nozīmīgām mutācijām: a) melanomas, b) krūts un dzemdes vēža smadzeṇu metastāžu preparātos 
2.3.1. tabula

Klīniski nozīmīgas TP53 gēna mutācijas

\begin{tabular}{|c|c|c|c|}
\hline Paraugs & $\begin{array}{c}\text { Izmaiņas } \\
\text { DNS }\end{array}$ & Izmaiṇas proteīnā & Histologiskā forma \\
\hline \multirow[t]{2}{*}{$\mathrm{D} 3 \mathrm{~b}$} & c. $517 \mathrm{G}>\mathrm{A}$ & p.V173M (Substitution - Missense) & \multirow[t]{2}{*}{ Nezināms pirmavots } \\
\hline & c. $637 \mathrm{C}>\mathrm{T}$ & p.R213* (Substitution - Nonsense) & \\
\hline B1-1b & c. $738 \mathrm{G}>\mathrm{C}$ & p.M246I (Substitution - Missense) & Nezināms pirmavots \\
\hline B1-2a & c. $637 \mathrm{C}>\mathrm{T}$ & p.R213* (Substitution - Nonsense) & Krūts vēzis \\
\hline B3-5a & IV7+2insG & $\mathrm{Nav}$ & Krūts vēzis \\
\hline G2-3a & c.565delG & p.189fs246* (Frameshift) & $\begin{array}{l}\text { Gastrointestinālā trakta } \\
\text { vēzis }\end{array}$ \\
\hline $\mathrm{U} 4 \mathrm{a}$ & c. $743 \mathrm{G}>\mathrm{A}$ & p.R248Q (Substitution - Missense) & $\begin{array}{l}\text { Olnīcu un dzemdes } \\
\text { kakla vēzis }\end{array}$ \\
\hline $\mathrm{L} 4-2 \mathrm{~b}$ & c. $743 \mathrm{G}>\mathrm{A}$ & p.R248Q (Substitution - Missense) & Plaušu vēzis \\
\hline R1a & IV7+2insG & $\mathrm{Nav}$ & Nieru vēzis \\
\hline M1-7b & c.740insC & p.247fs263* (Frameshift) & Melanoma \\
\hline M1-1b & $\begin{array}{l}\text { c.722_723CC } \\
>\mathrm{TT}\end{array}$ & p.S241F (Substitution - Missense) & Melanoma \\
\hline B3-3a & c. $542 \mathrm{G}>\mathrm{C}$ & p.R181P (Substitution - Missense) & Krūts vēzis \\
\hline
\end{tabular}

Salīdzinot grupas ar un bez TP53 gēna konstatētām klīniski nozīmīgām mutācijām, tika iegūti turpmāk minētie dati (skat. 2.3.2.tabulu).

2. 3.2. tabula

Grupu TP53 (+) un TP53 (-) salīdzinošie rādītāji

\begin{tabular}{|c|c|c|c|c|}
\hline & $\begin{array}{c}\text { TP53 (+) } \\
\text { mutācijas }\end{array}$ & $\begin{array}{c}\text { TP53(-) } \\
\text { mutācijas }\end{array}$ & p-vērtība & d vērtība \\
\hline Pacientu skaits & 11 & 29 & & - \\
\hline $\begin{array}{l}\text { Vidējais } \\
\text { vecums }\end{array}$ & $\begin{array}{l}M=61,45 \\
S D=13,10\end{array}$ & $\begin{array}{l}M=56,86 \\
S D=9,40\end{array}$ & 0,24 & 0,40 \\
\hline Vīrieši & 4 & 16 & 0,28 & - \\
\hline Sievietes & 7 & 13 & & \\
\hline $\begin{array}{l}\text { Vid. } K P S \\
\text { vērtība }\end{array}$ & $\begin{array}{l}M=64,55 \\
S D=9,34\end{array}$ & $\begin{array}{l}M=62,07 \\
S D=9,77\end{array}$ & 0,47 & 0,25 \\
\hline Vid. $R P A$ & $\begin{array}{l}\mathrm{M}=2,09 \\
\mathrm{SD}=0,94\end{array}$ & $\begin{array}{l}\mathrm{M}=2,38 \\
\mathrm{SD}=0,82\end{array}$ & 0,34 & 0,32 \\
\hline $\begin{array}{l}\text { Vidējāa } \\
\text { dzīvildze }\end{array}$ & 3,7 & 5,33 & 0,47 & - \\
\hline
\end{tabular}


Manna-Vitnija U tests norādīja, ka TP53 gēna mutāciju gadījumā vidējais vecums statistiski ticami neatškīiās $(\mathrm{p}=0,14)$ no to pacientu vecuma, kam TP53 gēna mutācijas netika konstatētas. Pīrsona hī-kvadrāta statistiskā analīzē tika konstatēts, ka TP53 gēna mutāciju esamība statistiski ticami neietekmē pacienta vecuma grupu $(\mathrm{p}=0,06)$. Pīrsona hī-kvadrāta statistiskā analīze norādīja, ka TP53 gēna mutāciju esamība statistiski ticami neietekmē metastāžu skaitu ( $\mathrm{p}=$ 0,41), kā arī to, ka TP53 gēna mutāciju esamība statistiski ticami neietekmē krūts vēža esamību $(\mathrm{p}=0,19)$.

11 to pacientu grupai, kuru evakuētajās cerebrālajās metastāzēs tika konstatētas TP53 gēna mutācijas, vidējā dzīvildze bija 3,7 mēneši (95\% TI: 0,93-6,46), turpretī tiem 29 pacientiem, kuriem netika konstatētas klīniski nozīmīgas TP53 gēna mutācijas, vidējā dzīvildze attiecīgi bija 5,33 mēneši (95 \% TI: 4,32-6,33).

Pamatojoties uz log-rank testu, tika secināts, ka TP53 gēna mutācijas statistiski ticami neietekmē pēcoperācijas dzīvildzi $(p=0,47)$.

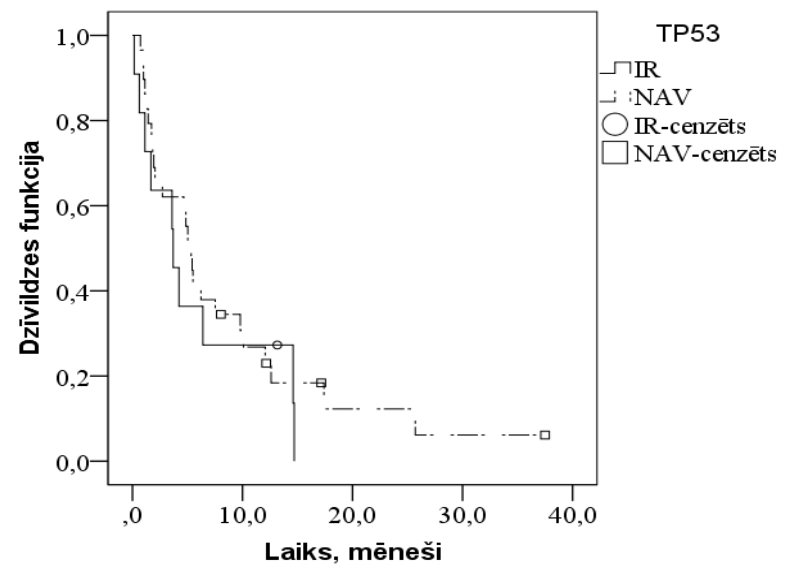

\subsection{2. attēls. Kaplana-Meijera dzīvildzes līkne pacientu grupām ar/bez konstatētām klīniski nozīmīgām TP53 gēna mutācijām}




\section{SECINĀJUMI}

1. Divu un vairāku galvas smadzeņu metastāžu ķirurğiska evakuācija ḷauj pagarināt dzīvildzi un saglabāt pacienta funkcionālo stāvokli noteiktu laika intervālu pēc operācijas.

2. Labāki divu un vairāku cerebrālu metastāžu ķirurgisiskas ārstēšanas rezultāti iegūti pacientu grupai ar 2-3 metastāzēm pēc radikālas un totālas visu diagnosticēto mezglu evakuācijas.

3. Statistiski nozīmīga ietekme uz labāku dzìvildzes prognozi postoperatīvi ir šādiem faktoriem: metastāžu skaitam, radikālai metastāžu evakuācijai, pirmsoperācijas KPS un RPA klases rādītājiem.

4. Dzīvildzes prognoze pacientiem ar oligometastāzēm (mediānā dzīvildze - 5,5 mēneši) ir 2,66 reizes garāka nekā pacientiem ar multiplām cerebrālām metastāzēm (mediānā dz̄ivildze - 2,06 mēneši) $(\mathrm{p}<0,05)$.

5. Kompleksas terapijas (WBRT vai $W B R T$ un ķīmijterapija) pielietojums parciālas smadzeņu metastāžu evakuācijas gadījumā dod nelielu dzīvildzes pagarinājumu salīdzinājumā ar daļēju, tikai ķirurǵisku metastāžu evakuāciju.

6. Pirmo 16 Latvijā radioķirurǵgiski ārstēto pacientu izvērtējums, kuriem bija nelielas (līdz $3 \mathrm{~cm}$ diametrā) cerebrālās metastāzes, uzrāda pozitīvus rezultātus, kuri prasa tālākus pētījumus un analīzi.

7. Histoloǵiskā materiāla genētiskajā analīzē (11 novērojumos no 40) tika konstatētas klīniski nozīmīgas TP53 gēna mutācijas. Statistiski nozīmīga ietekme starp pēcoperācijas dzīvildzi un TP53 gēna mutācijām pētījumā netika konstatēta. 


\section{PRAKTISKĀS REKOMENDĀCIJAS}

1. Pacientiem ar divām līdz trim galvas smadzeņu metastāzēm kā optimālākā rekomendējama tieši ķirurgíska, maksimāli radikāla visu diagnosticēto metastāžu mezglu evakuācija anatomiski un funkcionāli iespējamās robežās.

2. Gadījumos, kad smadzeṇu metastāžu evakuācija bijusi parciāla, tālākā terapijā rekomendē pielietot WBRT un atsevišķos - klīniski labvēlīgas situācijas gadījumos - arī individualizētu ķ̄imijterapiju.

3. Radioķirurǵija rekomendējama kā nozīmīga izvēles ārstēšanas metode nelielu (līdz $3 \mathrm{~cm}$ diametrā) vienas, divu vai vairāku galvas smadzeņu metastāžu gadījumos. 


\section{PUBLIKĀCIJAS}

1. Multiplu cerebrālu metastāžu slimnieku ārstēšanas rezultāti KUS „Gaiḷezers” neiroķirurğijas klīnikā 2002.-2007. gadā. K.Auslands, J.Ozoliņš, D.Apškalne, R.Ozols. RSU Zinātniskie raksti, 2008; 184-189.

2. Initial Experience with using frameless image - guided radiosurgery for the treatment of brain metastases. Liepa Zanda, Auslands Kaspars, Apškalne Daina, Ozols Rolfs. Exp Oncol, 2012; 34(2): 125-128.

3. Postoperative Survival in Patients With Multiple Brain Metastases. Auslands Kaspars, Apškalne Daina, Bicans Karlis, Ozols Rolfs, Ozolins Henrijs. Medicina(Kaunas), 2012; 48(6): 281-5.

4. Влияние клинических факторов на продолжительность жизни в послеоперационном периоде у больных с множественными метастазами головного мозга. Аусландс К.Я., Карклиня Ю.В., Апшкалне Д. Л., Озолс Р.Я. Нейрохирургия, 2013; 1: 23-31. 


\section{TĒZES UN DALĪBA STARPTAUTISKAJĀS KONFERENCĒS}

1. Auslands K. , Apškalne D., Ozols R. 5-year experience using surgical treatment for the patients with multiple brain metastases. EANS Young Neurosurgeons meeting. 2012.

2. Auslands K., Apškalne D., Ozols R. Surgical treatment results of patients with multiple brain metastases. $12^{\text {th }}$ Congress of Baltic Neurosurgical Association. 2012.

3. Liepa Z., Auslands K., Apškalne D., Ozols R. Initial experience with using frameless image-guided radiosurgery for the treatment of brain metastases. EANO (EUROPEAN ASSOCIATION OF NEUROONCOLOGY) congress. 2012.

4. Auslands K., Apškalne D., Ozols R. Combined treatment results in patients with multiple brain metastases. $5^{\text {th }}$ International Neurosurgery Meeting in Chamonix. 2013.

5. Auslands K., Apškalne D., Ozols R. Long-Term Survival of a Patient with Recurrent Brain Metastasis from Stage IV Melanoma Treated with Frameless Radiosurgery and Craniotomies: A case Report. 5th International Neurosurgery Meeting in Chamonix. 2013.

6. Auslands K., Apškalne D., Ozols R. Combined treatment results in patients with multiple brain metastases, a single center experience. EORTC-EANO-ESMO. Trends in Central Nervous System Malignancies. 2013. 


\section{TĒZES UN UZSTĀŠANĀS KONFERENCĒS LATVIJĀ}

1. Auslands K., Ozoliņš. J., Apškalne D., Ozols R. Multiplu cerebrālu metastāžu slimnieku ārstēšanas rezultāti KUS „Gaiḷezers” neiroķirurǵijas klīnikā (2002.-2007. gads). RSU Zinātniskā konference. 2007.

2. Auslands K., Ozoliņš J., Apškalne D., Ozols R. Multiplu cerebrālu metastāžu slimnieku ārstēšanas metodes RAKUS „Gaiḷezers” Neiroķirurğijas klīnikā. RSU Zinātniskā konference. 2010. 


\section{LITERATŪRAS SARAKSTS}

1. Bindal R.K., Sawaya R., Leavens M.E., Lee J.J. Surgical treatment of multiple brain metastases. J Neurosurg, 1993; 79: 210-216.

2. Chang E.L., Wefel J.S., Maor H., et al. A pilot study of neurocognitive function in patients with one to three new brain metastases initially treated with stereotactic radiosurgery alone. Neurosurgery, 2007; 60(2): 277-283.

3. Delattre J.Y., Krol G., Thaler H.T., Posner JB. Distribution of brain metastases. Arch Neurol, 1988; 45: 741-744.

4. Ding L., Ellis MJ., Li S., et al. Genome remodeling in a basal-like breast cancer metastasis and xenograft. Nature, 2010; 464: 999-1015.

5. Do L., Pezner R., Radany E., Liu A., Staud C., and Badie B. Resection followed by stereotactic radiosurgery to resection cavity for intracranial metastases. International Journal of Radiation Oncology Biology Physics, 2009; 73(2): 486-491.

6. Gaspar L., Scott C., Rotman M., Asbell S., Phillips T., Wasserman T., McKenna W.G., Byhardt R. Recursive partitioning analysis (RPA) of prognostic factors in three Radiation Therapy Oncology Group (RTOG) brain metastases trials. Int J Radiat Oncol Biol Phys, 1997; 37: 745-751.

7. Gavrilovic T., Posner JB. Brain metastases: epidemiology and pathophysiology. Journal of Neuro-Oncology, 2005; 75(1): 5-14.

8. Jagannathan J., Yen C.P., Ray D.K., et al.Gamma Knife radiosurgery to the surgical cavity following resection of brain metastases: clinical article. Journal of Neurosurgery, 2009; 111(3): 431-438.

9. Kocher M., Soffietti R., Abacioglu U., et al. Adjuvant whole-brain radiotherapy versus observation after radiosurgery or surgical resection ofone to three cerebral metastases: results of the EORTC 22952-26001 study. Journal of Clinical Oncology, 2011; 29(2): 134-141.

10. Meyers C.A., Smith J.A., Bezjak A., et al. Neurocognitive function and progression in patients with brain metastases treated with whole-brain radiation and motexafin gadolinium: results of a randomized phase III trial. Journal of Clinical Oncology, 2004; 22(1): 157-165.

11. Nigro C.Lo., Vivenza D., Monteverde M., et al. High frequency of complex TP53 mutations in CNS metastases from breast cancer. British Journal of Cancer, 2012; 106: 397-404.

12. Pharaoah P.D., Day NE., Caldas C. Somatic mutations in the p53 gene and and prognosis in breast cancer: a meta-analysis. Br J Cancer, 1999; 80: 1968-1973.

13. Sawaya R., Bindal R.K. Metastatic brain tumors. In Kaye A.H., Laws E.(eds). Brain Tumors. Edinburgh: Churchill Livingstone; 1995: 923-946.

14. Schouten L.J., Rutten J., Huveneers H.A., Twijnstra A. Incidence of brain metastases in a cohort of patients with carcinoma of the breast, colon, kidney, lung and melanoma. Cancer 2002; 94:2 698-2705

15. Soffietti R., Ruda R., Mutani R. Management of brain metastases. Journal of Neurology, 2002; 249(10): 1357-1369.

16. Soffietti R., Ruda R., Trevisan E. Brain metastases: current management and new developments. Current Opinion in Oncology, 2008; 20(6): 676-684. 
17. Soffirtti R., Cornu P., Delattre J.Y., et al. EFNS Guidelines on diagnosis and treatment of brain metastases: report of an EFNS Task Force. Eur J Neurol 2006; 13: 674-81.

18. Sperduto P.W., Berkey B., Gaspar L.E., et al. A new prognostic index and comparison to three other indicēs for patients with brain metastases: an analysis of 1,960 patients in the RTOG database. Int J Radiat Oncol Biol Phys, 2008; 70: 510-514.

19. Sperduto P.W., Chao S.T., Sneed P.K., et al. Diagnosis- specific prognostic factors, indexes, and treatment outcomes for patients with newly diagnosed brain metastases: a multi-institutional analysis of 4,259 patients. Int J Radiat Oncol Biol Phys, 2010; 77: 655-661. 


\section{PATEICĪBAS}

Izsaku pateicību darba vadītājai docentei Dainai Apškalnei par nenovērtējamu palīdzību un atbalstu darba tapšanas laikā.

Pateicos RSU Zinātņu prorektorei Dr. habil. med. profesorei Ivetai Ozolantai par atbalstu darba izstrādēs laikā.

Paldies profesoram Andrejam Milleram par atbalstu darba izstrādes laikā.

Paldies Dr. habil. med. profesorei Gaidai Krūmiņai un profesoram Edvīnam Miklaševičam par palīdzību darba izstrādē.

Pateicos RAKUS Staru terapijas nodaļas vadītājai dr. Zandai Liepai par atbalstu un sadarbību darba izstrādē un RSU Fizikas katedras docentam Renāram Ertam par palīdzību datu statistiskajā apstrādē.

Paldies RAKUS klīnikas „Gaiļezers” nodaļas vadītājam Kārlim Bicānam, 16. neiroķirurg̣ijas nodaļas kolēgiem, kā arī Patologijas centra vecākajai laborantei Tamārai Čukḷinai par palīdzību darba izstrādē.

Paldies manai sievai Baibai, bērniem Jānim un Dārtai un maniem vecākiem Zentai un Jānim Auslandiem par nenovērtējamu atbalstu. 